\title{
PENGARUH PENGETAHUAN KEUANGAN, PENGALAMAN KEUANGAN, TINGKAT PENDAPATAN, DAN TINGKAT PENDIDIKAN TERHADAP PERILAKU KEUANGAN
}

\begin{tabular}{|c|c|}
\hline \multicolumn{2}{|c|}{$\begin{array}{c}\text { Lisna Devi }^{1} \text {, Sri Mulyati }{ }^{2} \text {, Indah Umiyati } \\
{ }^{3} \text { STIE Sutaatmadja, Subang - Indonesia } \\
\text { lisnadevi76@gmail.com }\end{array}$} \\
\hline INFO ARTIKEL & ABSTRAK/ABSTRACT \\
\hline $\begin{array}{l}\text { Histori Artikel : } \\
\text { Tgl. Masuk : } 11 \text { Januari } 2021 \\
\text { Tgl. Diterima : } 05 \text { Maret } 2021 \\
\text { Tersedia Online : } 31 \text { Maret } 2021 \\
\text { Keywords: } \\
\text { Pengetahuan Keuangan, } \\
\text { Pengalaman } \\
\text { Keuangan, Tingkat } \\
\text { Pendapatan, Tingkat } \\
\text { pendidikan, dan Perilaku } \\
\text { Keuangan. }\end{array}$ & $\begin{array}{l}\text { Tujuan Penelitian ini adalah untuk mengetahui pengaruh } \\
\text { pengetahuan keuangan, pengalaman keuangan, tingkat } \\
\text { pendapatan, dan tingkat pendidikan terhadap perilaku } \\
\text { keuangan keluarga. Jenis penelitian yang digunakan dalam } \\
\text { penyusunan penelitian ini adalah kuantitatif. Data primer } \\
\text { yang diperoleh dari responden dengan teknik pengumpulan } \\
\text { data berupa kuesioner. Populasi dalam penelitian ini yaitu } \\
\text { kepala keluarga di Subang dengan sampel sebanyak } 120 \\
\text { responden. Adapun metode analisis yang digunakan } \\
\text { adalah uji validitas dan reliabilitas. Uji Normalitas Uji } \\
\text { Heterokedastisitas dan Uji Multikolonieritas. Uji t, Uji F dan } \\
\text { koefisien determinasi. Hasil uji hipotesis secara parsial } \\
\text { menunjukkan bahwa pengetahuan keuangan, tingkat } \\
\text { pendaptan, dan tingkat pendidikan tidak berpengaruh } \\
\text { terhadap perilaku keuanga keluarga, sedangkan } \\
\text { pengalaman keuangan berpengaruh postif signifikan } \\
\text { teradap perilaku keuangan keluarga. Hasil uji hipotesis } \\
\text { secara simultan menunjukkan bahwa pengetahuan } \\
\text { keuangan, pengalaman keuangan, tingkat pendapatan, } \\
\text { dan tingkat pendidikan secara simultan berpengaruh positif } \\
\text { signifikan terhadap perilaku keuangan keluarga. } \\
\text { Berdasarkan uji Tdan uji F maka hipotesis penelitian dapat } \\
\text { diterima pada tingkat signifikansi } 5 \% \text {. }\end{array}$ \\
\hline
\end{tabular}

PENDAHULUAN

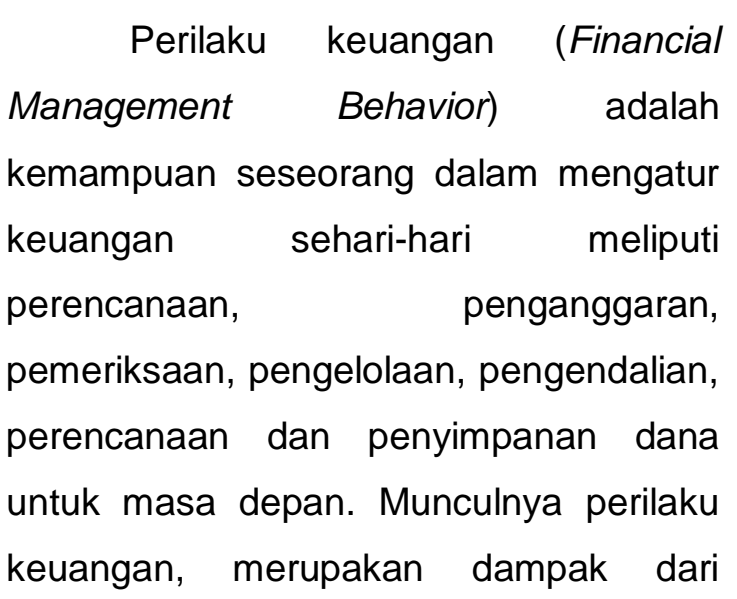

besarnya hasrat seseorang untuk memenuhi kebutuhan hidupnya sesuai dengan tingkat pendapatan yang diperoleh (Kholilah dan Iramani, 2013), oleh sebab itu pentingnya perilaku keuangan demi keberlangsungan usaha dan hidup seseorang dalam memenuhi kebutuhan sehari-hari.

Fenomena yang terjadi di kalangan masyarakat mengenai Perilaku keuangan 
(Financial Management Behavior) berkaitan dengan perilaku konsumsi masyarakat yang cenderung berubah diakibatkan perkembangan zaman yang tumbuh begitu pesatnya terutama perkembangan informasi dan teknologi, sering masyarakat temui dalam memenuhi kebutuhannya masyarakat sering kali didorong oleh motif tertentu untuk mendapatkan barang atau jasa yang dibutuhkannya. Masyarakat Indonesia saat ini menjadi sangat konsumtif terhadap apapun yang dilihatnya tanpa melihat bahwa hal tersebut merupakan kebutuhan atau hanya keinginan semata, cenderung berfikir jangka pendek tanpa diikuti tanggung jawab sosial baik dari masyarakat kalangan menengah keatas maupun masyarakat kalangan menengah kebawah tidak akan lepas dari perilaku konsumtif tersebut (Alfida \& Nurul, 2018).

Perilaku keuangan masyarakat Indonesia yang cenderung konsumtif, tidak hanya terjadi di kota-kota besar saja akan tetapi sudah merambah ke kota-kota kecil bahkan pedesaan di Indonesia, masyarakat memiliki perilaku keuangan yang tidak bertanggung jawab akibat dari timbulnya perilaku konsumtif seperti kurangnya menabung, investasi, perencanaan darurat dan penganggaran dana untuk masa depan. Perkembangan teknologi yang semakin pesat terutama dalam perkembangan e-commerce atau binis online sangat mendukung terjadinya gaya hidup konsumtif yang serba instan sehingga masyarakat tertarik untuk membeli barang yang diinginkan meskipun barang tersebut tidak dibutuhkan (Alfida \& Nurul, 2018).

Saat ini kebutuhan dan keinginan setiap manusia semakin tinggi, sehingga setiap individu yang berada pada zaman serba modern saat ini diharuskan memiliki kemampuan dalam mengelola keuangannya, hal ini dikarenakan banyak sekali permasalahan yang dialami menyangkut dengan pengelolaan keuangan. Keadaan masyarakat khususnya yang sudah berkeluarga dituntut untuk bisa bekerja lebih keras agar dapat memenuhi kebutuhan serta dalam pengelolaan keuangan diharapkan penerapannya benar dan tepat, maka dengan itu setiap individu mendapatkan manfaat yang maksimal dari uang yang dimilikinya. Penerapan yang tepat dalam mengelola keuangan keluarga dapat meningkatkan keharmonisan keluarga (Melliza, 2017).

Menurut Ida dan Dwinta (2010) menjelaskan bahwa Financial Management Behavior berhubungan dengan tanggung jawab keuangan seseorang mengenai cara pengelolaan keuangan individu. Keluarga yang dapat mengelola keuangannya dengan benar dan tepat menunjukkan bahwa keluarga tersebut sudah dapat bertanggung jawab atas uang yang dimilikinya. Tanggungjawab seseorang dapat dinilai dari kecenderungan diri dalam 
menghemat uang yang dimiliki, mengelola anggaran, serta mengontrol pengeluaran (Perry dan Morris, 2005). Dalam mengelola keuangan membutuhkan pengetahuan dalam menjalankannya, selain itu kemampuan individu untuk dapat membuat keputusan yang efektif mengenai keuangan pribadi merupakan suatu hal berguna untuk pengaturan keuangan. Pengelolaan keuangan keluarga menjadi sangat penting karena kegagalan dalam mengelola keuangan akan berdampak negatif dalam jangka panjang (Perry \& Morris, 2005).

Pengetahuan keuangan akan sangat penting fungsinya bagi yang sudah berkeluarga. Pemahaman tentang pengetahuan keuangan mendorong seseorang untuk berperilaku baik dalam pengelolaan keuangannya untuk jangka panjang. Tingginya pengetahuan keuangan seseorang akan cenderung memiliki prilaku keuangan yang baik (Andrew, 2014). Menurut Kholilah dan Iramani (2013) untuk menangani keuangan pribadi secara sistematika dan berhasil maka diperlukan pengetahuan. Pengetahuan keuangan (Financial Knownledge) yang semakin baik akan mempunyai potensi yang meningkatan perekonomian nasional karena individu sadar akan pentingnya mengelola keuangan. Yusnia dan Jubaedah (2017) pengetahuan keuangan berpengaruh terhadap perilaku keuangan. Sedangkan Lianto dan Elizabeth (2017) pengetahuan keuangan tidak berpengaruh terhadap perilaku keuangan.

Menurut Tarihoran, Literasi dan Edukasi Keuangan OJK di Negara Indonesia menjelaskan bahwa banyak masyarakat Indonesia saat ini yang membeli produk dan menggunakan jasa, tidak benar-benar paham apa yang dibeli dan digunakannya serta literasi keuangan masyarakat sangat rendah (Tirto.id, 2017). Kondisi ini menunjukkan Indonesia harus bersaing lebih ketat lagi dalam perekonomian dunia, diantaranya harus lebih efektif dalam memilih produk atau jasa yang nantinya ditawarkan, masyarakat menambah informasi mengenai literasi keuangan serta waspada dalam investasi. Menurut Survei Nasional Literasi dan Inklusi Keuangan (SNLIK) 2016 yang dilakukan Otoritas Jasa Keuangan (OJK) literasi keuangan. Di Indonesia baru menjadi 29,66\% tahun 2016, masih ada sekitar $70,44 \%$ penduduk Indonesia dikatakan tingkat literasi keuangannya masih rendah (Press Release Halomoney, 12 Juli 2017). Grafik 1.1 menunjukkan tentang Indek Literasi Keuangan. 


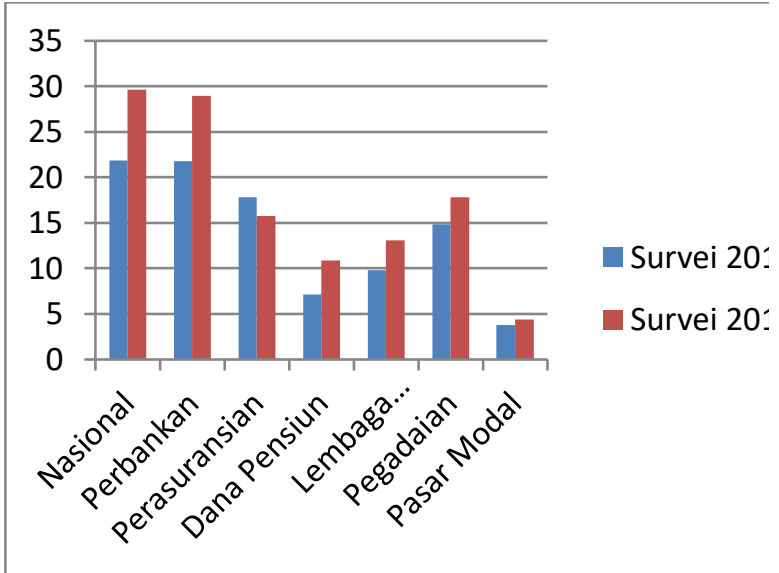

Gambar 1.1

Indek Literasi Keuangan

Sumber : OJK, 2016

Namun, peningkatan ini tidak diimbangi dengan pengetahuan di seluruh lapisan masyarakat mengenai produkproduk keuangan dan literasi keuangan yang masih minim sekali dan sudah dijelaskan sebelumnya. Menurut Horas VM Tarihoran selaku Direktur Literasi dan Edukasi Keuangan OJK telah menjelaskan masih banyak masyarakat Indonesia yang membeli produk dan menggunakan jasa lembaga keuangan, tetapi masyarakat tidak benar-benar memahami apa yang dibeli dan digunakannya seakan masyarakat menggunakannya hanya iming-iming saja tanpa dibekali pengetahuan dengan baik (Tirtod.id, 2017). Adapun, Survei Otoritas Jasa Keuangan Nasional pada akhir 2016 menyebutkan bahwa indeks literasi keuangan 29,66 lebih kecil dari indeks inklusi keuangan $67,82 \%$ yang menunjukkan kecenderungan sebagian besar masyarakat memanfaatkan atau menggunakan produk jasa dan produk keuangan tanpa disertai pemahaman atau literasi keuangan memadai. Stabil perekonomian Indonesia tidak lepas dari pengaruh dalam bidang keuangan. Dimana salah satu sistem keuangan berfungsi mempercepat pertumbuhan ekonomi, lebih meratakan pertumbuhan dengan menyebarkan manfaatnya keseluruh lapisan masyarakat. Salah satu jenis kegiatan berperan penting dalam pertumbuhan dibidang keuangan adalah investasi baik secara luas seperti investasi dalam negeri maupun luar negeri dan kegiatan investasi masyarakat negara itu sendiri.

Menurut Ritma dan Untung (2015), pengalaman keuangan adalah kejadian tentang hal yang pernah dialami (dijalani, dirasakan, ditanggung dan sebagainya) baik yang sudah lama atau baru saja terjadi. Dari pengalaman keuangan dapat digunakan untuk modal dalam mengelola keuangan. Pengalaman pada setiap individu dalam mengelola keuangannya tentu berbeda-beda, seperti dengan merencanakan investasi, asuransi, dana pensiun, dan kredit. Pengalaman seseorang saat mengelola keuangan sangat dibutuhkan dengan berlangsungnya hidup di masa yang akan datang. Purwidianti dan Mudjiyanti (2016) pengalaman keuangan berpengaruh terhadap perilaku keuangan. Sedangkan hasil penelitian Widyaningrum (2018) pengalaman keuangan tidak berpengaruh terhadap perilaku pengelolaan keuangan keluarga di Sidoarjo. 
Tingkat pendapatan merupakan total pendapatan kotor seorang individu tahunan yang berasal dari upah, perusahaan bisnis serta berbagai investasi. Penghasilan pribadi juga dikenal sebagai "laba sebelum pajak" anda dan digunakan dalam perhitungan laba kotor disesuaikan seseorang untuk tujuan pajak penghasilan (Lianto dan Elizabeth, 2017). Reviandani (2019) tingkat pendapatan berpengaruh terhadap perilaku keuangan. Sedangkan hasil penelitian Purwidianti dan Mudjiyanti (2016) tingkat pendapatan tidak berpengaruh terhadap perilaku keuangan keluarga.

Dalam kaitannya memahami perilaku keuangan, latar belakang pendidikan juga memiliki pengaruh terhadap pemahaman dan pengetahuan yang dimilikinya. Pendidikan adalah proses individu belajar untuk memahami sesuatu yang belum dipahami. Dengan pendidikan formal yang memadai individu akan lebih mudah untuk mengerti dan memahami perilaku keuangan yang baik dan bijaksana dalam mengambil keputusan perilaku keuangannya (Mahmudah, 2018). Mahmudah (2018) tingkat pendidikan berpengaruh terhadap perilaku keuangan PNS wanita di Surabaya. Sedangkan hasil penelitian Paramitha (2017) tingkat pendidikan tidak berpengaruh terhadap perilaku keuangan keluarga.

Kholilah dan Iramani, (2013), perilaku keuangan adalah kemampuan seseorang dalam mengatur yaitu perencanaan, penganggaran, pemeriksaan, pengelolaan, pengendalian, pencarian dan penyimpanan dana keuangan sehari-hari. Munculnya financial behavior, merupakan dampak dari besarnya hasrat seseorang untuk memenuhi kebutuhan hidupnya sesuai dengan tingkat pendapatan yang diperoleh (Kholilah dan Iramani, 2013) dalam literatur psikologi banyak diuraikan bahwa aspek keperilakuan memegang peranan penting pada setiap proses pembuatan keputusan. Hal ini dapat dipahami karena manusia pada dasarnya adalah makhluk yang memiliki akal (rasio) dan emosi. Seseorang tidak bisa mengklaim bahwa dirinya selalu seratus persen rasional dalam membuat keputusan. Sebaliknya ia tidak bisa hanya selalu hanya mengandalkan emosi untuk mendasari segala keputusan yang dibuatkannya (Asri 2013, hlm. 221).

Penelitian ini melanjutan penelitian Purwidianti dan Mudjiyanti (2017), serta Reviandi (2019), yang sudah melakukan penelitian mengenai pengalaman dan tingkat pendapatan terhadap perilaku keuangan. Penelitian ini menambahkan variabel pengetahuan keuangan dan tingkat pendidikan berdasarkan penelitian Rustiaria (2017).

Penelitian ini dilakukan di kota Subang, dengan pertimbangan bahwa kota Subang merupakan salah satu kota yang berpotensi maju. Sebagian besar 
wilayah di bagian selatan kabupaten Subang berupa perkebunan, baik perkebunan Negara maupun perkebunan rakyat, hutan dan lokasi pariwisata. Bagian tengah wilayah kabupaten Subang berkembang perkebunan karet, tebu dan buah-buahan dibidang pertanian dan pabrik-pabrik dibidang Industri, selain perumahan dan pusat pemerintahan serta instalasi militer. Kemudian di bagian utara wilayah Kabupaten Subang berupa sawah berpengairan teknis dan tambak serta pantai.

Dari uraian di atas, penulis tertarik untuk melakukan penelitian yang berjudul "Pengaruh Pengetahuan Keuangan, Pengalaman Keuangan, Tingkat Pendapatan, dan Tingkat Pendidikan Terhadap Perilaku Keuangan" (Studi Kasus Pada Kepala Keluarga Di Kabupaten Subang).

\section{KERANGKA TEORITIS DAN PENGEMBANGAN HIPOTESIS}

\section{Grand Theory}

Theory of Planned Behavior (Teori Perilaku Rencanaan)

Theory of Planned Behavior (TPB) yang merupakan pengembangan dari Theory of Reasoned Action (TRA) (Ajzen dalam Jogiyanto, 2007). Jogiyanto (2007) Mengembangkan teori ini dengan menambahkan konstruk yang belum ada di TRA. Konstruk ini di sebut dengan kontrol perilaku persepsian (perceived behavioral control). Konstruk ini ditambahkan di TPB untuk mengontrol perilaku individual yang dibatasi oleh kekurangan-kekurangannya dan keterbatasan-keterbatasan dari kekurangan sumber-sumber daya yang digunakan untuk melekukan perilakunya (Hsu and Chiu 2002).

Planned Behavior Theory (TPB) telah banyak diaplikasikan untuk memahami bagaimana individu berperilaku dan bagaimana cara menunjukkan reaksi. Teori ini merupakan salah satu teori psikologi sosial yang memprediksi perilaku manusia. Alasan utama perilaku pengambilan keputusan merupakan hasil dari proses reasoning yang dipengaruhi oleh sikap, norma dan pengendalian perilaku (Smith et al. 2007). Lebih lanjut, Sommer (2011) mengatakan bahwa perilaku manusia bisa disebabkan oleh alasan-alasan/kemungkinan yang berbeda, hal ini berarti bahwa keyakinan seseorang tentang konsekuensi dari sikap/perilaku, keyakinan akan ekspektasi terhadap orang lain dan adanya faktorfaktor yang mungkin menghalangi perilaku tersebut. Teori ini menunjukkan bahwa latar belakang seperti gender, usia, pengalaman, pengetahuan akan mempengaruhi keyakinan seseorang terhadap sesuatu yang pada akhirnya akan mempengaruhi perilaku seseorang tersebut.

\section{Pengetahuan Keuangan}

Pengetahuan menuang ke apa yang diketahui seseorang mengenai masalah keuangan pribadinya, yang diukur dengan tingkat pengetahuan mereka tentang berbagai konsep keuangan pribadi dalam Mars (2006). Pengetahuan keuangan yaitu pemahaman atau kesanggupan seseorang tentang berbagai hal mengenai dunia keuangan (Kholilah dan Iramani, 2013). Pada perkembangannya, pengetahuan mengenai keuangan mulai diperkenalkan di berbagai jenjang pendidikan. Terdapat berbagai sumber pengetahuan yang dapat diperoleh, termasuk pendidikan formal, seperti 
program sekolah tinggi atau kuliah, seminar, serta sumber-sumber informasi, seperti lingkungan masyarakat, teman, dan lingkungan pekerjaan (Ida dan Dwinta, 2010).

Pengetahuan keuangan itu sangat penting, tak hanya kepentingan individu saja, namun kepentingan yang lainnya. Pengetahuan keuangan tidak hanya mampu membuat anda menggunakan uang dengan bijak, namun juga dapat memberi manfaat pada ekonomi. Jadi, konsumen yang memiliki pengetahuan keuangan bagus akan mampu menggunakan uang sesuai dengan apa yang mereka butuhkan, sehingga ini akan mendorong para produsen untuk membuat produk atau jasa yang lebih sesuai dengan kebutuhan mereka (Ida dan Dwinta, 2010).

Orang dengan pengetahuan keuangan tinggi cenderung puas dengan keadaan keuangan dan terus meningkatkan kualitas hidup karena mengerti sepenuhnya atas keaadaan keuangannya saat ini dan cara memperbaikinya. Jadi apabila individu atau keluarga memiliki kemampuan untuk mengelola keuangan dengan baik serta menggunakan uangnya dengan bijak dan mengalokasikannya untuk memenuhi kebutuhan yang dibutuhkan maka tujuan yang diinginkan akan tercapai (Halim dan Astuti, 2015).

\section{Pengalaman Keuangan}

Menurut Ritma dan Untung (2015), pengalaman keuangan adalah kejadian tentang hal yang pernah dialami (dijalani, dirasakan, ditanggung dan sebagainya) baik yang sudah lama atau baru saja terjadi. Dari pengalaman keuangan dapat digunakan untuk modal dalam mengelola keuangan.

Pengalaman pada setiap individu dalam mengelola keuangannya tentu berbeda-beda, seperti dengan merencanakan investasi, asuransi, dana pensiun, dan kredit. Pengalaman seseorang saat mengelola keuangan sangat dibutuhkan dengan berlangsungnya hidup di masa yang akan datang. Pengalaman individu adalah suatu pembelajaran dimana mengelola keuangan ataupun perencanaan investasi sehingga dalam membuat keputusan keuangan setiap hari dapat terarah dan lebih bijak. Dengan kemajuan teknologi bisa memudahkan seseorang dalam melakukan suatu transaksi keuangan, seperti membeli saham secara online, maupun membayar tagihan (kartu kredit, KPR, bayar sekolah), pembayaran premi asuransi, serta membeli reksadana, dan lain-lain. Pengalaman setiap individu dalam penggunaan teknologi itu sendiri juga berbeda-beda tergantung dari pengetahuan akan teknologi. Pengalaman mengelola keuangan dapat juga sebagai pertimbangan dalam pengambilan keputusan keuangan maupun perencanaan investasi (Pritazahara dan Sriwidodo, 2015).

Pengalaman keuangan adalah kejadian mengenai hal-hal yang berhubungan dengan keuangan yang pernah dialami (dijalani, dirasai, ditanggung, dan sebagainya) baik yang sudah atau sedang terjadi (Norma Yulianti dan Meliza Silvy, 2013). Pengalaman keuangan digunakan sebagai modal dalam mengelola keuangan. Pengelolaan keputusan keuangan yang baik dan benar dibutuhkan untuk meningkatkan pendapatan, mengelola pengeluaran pembayaran pajak agar manajemen keuangan keluarga menjadi baik. Pengalaman masa kecil yang positif tentang mengelola keuangan, lingkungan sosial, dan sikap terhadap penghematan memainkan peran manajemen keuangan dalam perilaku keuangan keluarga dimasa yang akan datang. Pengalaman dapat dipelajari dari pengalaman pribadi, teman, 
keluarga atau orang lain yang lebih berpengalaman sehingga memperbaiki dalam mengelola keuangan, pengambilan keputusan maupun perencanaan investasi. Pengalaman keuangan dapat diperoleh seorang pengelola keuangan dari transaksi-transaksi pengeluaran ataupun pengambilan keputusan keuangan keluarga. Pengelola keuangan keluarga pada umumnya telah memiliki pengalaman keluarga dengan berinvestasi pada aset riil tetapi belum pernah memiliki pengalaman investasi pada aset keuangan. Motivasi untuk kehidupan keluarga yang lebih baik juga berasal dari pembelajaran hidup dan belajar dari pengalaman itu sendiri, sehingga seorang pengelola keuangan keluarga harus lebih berhati-hati dalam pengambilan keputusan keuangan (Norma Yulianti dan Meliza Silvy, 2013).

\section{Tingkat Pendapatan}

Menurut Andrew dan Linawati (2014) menyatakan bahwa personal income adalah penghasilan pribadi sebelum pajak. Personal income dapat diukur berdasarkan pendapatan dari semua sumber. Komponen terbesar dari total pendapatan yaitu upah dan gaji.

Tingkat pendapatan merupakan total pendapatan kotor seorang individu tahunan yang berasal dari upah, perusahaan bisnis serta berbagai investasi. Penghasilan pribadi juga dikenal sebagai "laba sebelum pajak" anda dan digunakan dalam perhitungan laba kotor disesuaikan seseorang untuk tujuan pajak penghasilan (Lianto dan Elizabeth, 2017).

Tingkat Pendidikan

Menurut Undang-undang Nomor 2 tahun 1989 tentang Sistem Pendidikan
Nasional adalah sebagai berikut : "Pendidikan adalah usaha sadar untuk menyiapkan peserta didik melalui kegiatan bimbingan, pengajaran dan atau latihan bagi peranannya dimasa yang akan datang". Menurut Tim Pengembangan MKDK IKIP Semarang, "Pendidikan adalah usaha manusia untuk meningkatkan kepribadiannya dengan jalan membinapotensi-potensi pribadinya, yaitu rokhani (pikir, karsa, rasa, cipta dan budinurani) dan jasmani (panca indera serta keterampilanketerampilan)"(1995:5). Sedangkan menurut Dr.Nazili Shaleh Ahmad (1982:4)., "Pendidikan itu merupakan kegiatan proses belajar mengajar yang sistem pendidikannya senantiasa berbeda dan berubah-ubah, dari masyarakat yang satu kepada masyarakat yang lain". Pendapat lain tentang pengertian pendidikan dikemukakan oleh John S.Brubacher yang dikutip Sumitro (1998:17) menyatakan bahwa; "Pendidikan adalah proses dalam mana potensi-potensi,

kemampuankemampuan, kapasitas-kapasitas manusia yang mudah dipengaruhi oleh kebiasaan-kebiasaan, disempurnakan dengan kebiasaan-kebiasaan yang baik, dengan alat (media) yang disusun sedemikian rupa, dan digunakan oleh manusia untuk menolong orang lain atau dirinya sendiri dalam mencapai tujuantujuan yang telah ditetapkan".

Tingkat pendidikan adalah suatu proses jangka panjang yang menggunakan prosedur sistematis dan terorganisir, yang mana tenaga kerja manajerial mempelajari pengetahuan konseptual dan teoritis untuk tujuan-tujuan umum. Menurut Azyumardi Azra menyatakan bahwa tingkat pendidikan merupakan suatu kegiatan seseorang dalam mengembangkan kemampuan, sikap, dan bentuk tingkah lakunya, baik 
untuk kehidupan masa kini dan sekaligus persiapan bagi kehidupan masa yang akan datang dimana melalui organisasi tertentu ataupun tidak terorganisir. Dalam kamus besar bahasa indonesia tingkat pendidikan adalah tahap yang berkelanjutan yang ditetapkan berdasarkan tingkat perkembagan para peserta didik, keluasaan bahan pengajaran, dan tujuan pendidikan yang dicantumkan dalam kurikulum. Jadi dapat simpulkan bahwa tingkat pendidikan adalah suatu proses peserta didik dalam meningkatkan pendidikan sesuai dengan jenjang yang akan di tempuhnya dalam melanjutkan pendidikan yang ditempuh. Tingkat pendidikan ditempuh secara manajerial atau terorganisir (Adhanari, 2005).

\section{Perilaku Keuangan}

$\begin{array}{llr}\text { Financial } & \text { behaviour atau perilaku } \\ \text { keuangan } & \text { dapat } & \text { mempengaruhi } \\ \text { bagaimana } & \text { seseorang mengelola, }\end{array}$ memperlakukan serta menggunakan sumber daya keuangan yang ada. Individu yang memiliki financial behaviour yang bertanggung jawab cenderung efektif dalam menggunakan uang yang dimilikinya, misalnya membuat anggaran, menghemat uang, mengontrol belanja, berinvestasi, serta membayar kewajiban tepat waktu (Nababan dan sadalia, 2012).

Perilaku keuangan berkaitan dengan bagaimana seseorang mengelola, memperlakukan dan menggunakan sumber daya keuangan yang tersedia. Munculnya perilaku keuangan pada seorang individu didasari oleh keinginan untuk memenuhi kebutuhan hidupnya sesuai dengan pendapatan yang diperoleh. Pada penelitian sebelumnya (Mandell and Klein, 2009) menyimpulkan bahwa cara terbaik untuk meningkatkan perilaku keuangan adalah dengan mengajarkan perilaku yang baik sejak dini, termasuk perilaku keuangan. Perilaku keuangan menggambarkan tentang bagaimana seseorang memperlakukan, mengelola, dan menggunakan sumber keuangan yang dimilikinya (Suryanto, 2017).

Perilaku keuangan dapat diartikan sebagai aolikasi ilmu psikologi dalam disiplin ilmu keuangan. Perilaku keuangan merupakan analisis berinvistasi yang menggunakan ilmu psikologi dan ilmu keuangan, yaitu suatu pendekatan yang menjelaskan bagaimana manusia melakukan investasi atau berhubungan dengan keuangan. Perilaku keuangan bermaksud biasanya digunakan untuk memahami perilaku investor dalam mengambil keputusan investasi dan bertindak di pasar modal yang akan berpengaruh pada market performance (Shahzad dkk., 2013).

Kerangka Pemikiran

Penulis melakukan penelitian yang berjudul "Pengaruh pengetahuan keuangan, pengalaman keuangan, tingkat pendapatan, dan tingkat pendidikan terhadap perilaku keuangan". Perilaku keuangan dapat mempengaruhi bagaimana seseorang mengelola, memperlakukan serta menggunakan sumber daya keuangan yang ada. Individu yang memiliki financial behaviour yang bertanggung jawab cenderung efektif dalam menggunakan uang yang dimilikinya, misalnya membuat anggaran, menghemat uang, mengontrol belanja, berinvestasi, serta membayar kewajiban tepat waktu (Nababan dan sadalia, 2012). Pengetahuan keuangan yaitu pemahaman atau kesanggupan seseorang tentang berbagai hal mengenai dunia keuangan (Kholilah dan Iramani, 2013). Menurut Ritma dan Untung (2015), pengalaman keuangan adalah kejadian tentang hal yang pernah dialami (dijalani, dirasakan, ditanggung dan sebagainya) baik yang sudah lama atau baru saja terjadi. Dari pengalaman keuangan dapat digunakan untuk modal dalam mengelola keuangan. Tingkat pendapatan merupakan total 
pendapatan kotor seorang individu tahunan yang berasal dari upah, perusahaan bisnis serta berbagai investasi. Penghasilan pribadi juga dikenal sebagai "laba sebelum pajak" anda dan digunakan dalam perhitungan laba kotor disesuaikan seseorang untuk tujuan pajak penghasilan (Lianto dan Elizabeth, 2017). Tingkat pendidikan adalah suatu proses peserta didik dalam meningkatkan pendidikan sesuai dengan jenjang yang akan di tempuhnya dalam melanjutkan pendidikan yang ditempuh. Tingkat pendidikan ditempuh secara manajerial atau terorganisir (Adhanari, 2005).

Pentingnya perilaku keuangan dalam pengelolaan keuangan keluarga di Subang dinilai masih kurang dipahami oleh masyarakat hal ini dikarenakan banyak sekali permasalahan yang dialami menyangkut dengan pengelolaan keuangan. Dalam mengelola keuangan membutuhkan pengetahuan dalam menjalankannya, selain itu kemampuan individu untuk dapat membuat keputusan yang efektif mengenai keuangan pribadi merupakan suatu hal berguna untuk pengaturan keuangan. Pengelolaan keuangan keluarga menjadi sangat penting karena kegagalan dalam mengelola keuangan akan berdampak negatif dalam jangka panjang.

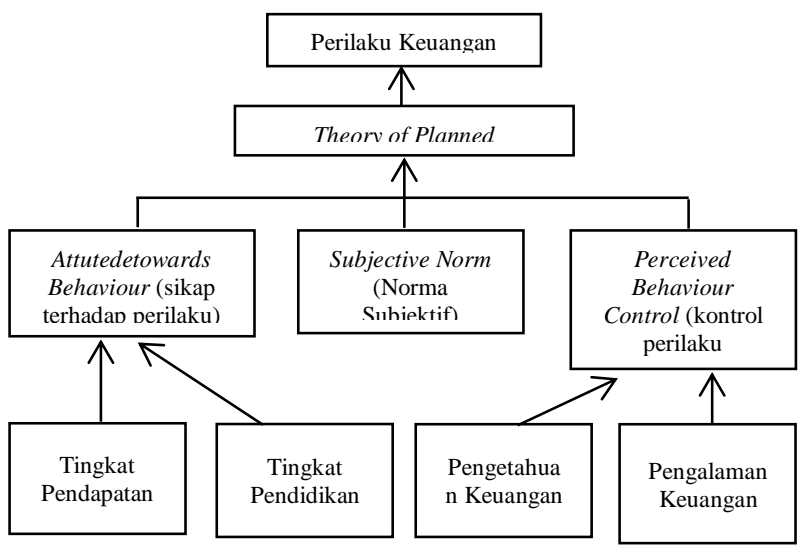

Gambar 2.1

Kerangka Pemikiran
Peneliti (2020)

Kerangka Penelitian

Kerangka hipotesis dalam penelitian ini terdiri dari empat variabel independen yaitu pengetahuan keuangan (X1), pengalaman keuangan (X2), tingkat pendapatan (X3), dan tingkat pendidikan (X4) serta variabel dependen yaitu perilaku keuangan (Y). Berdasarkan landasan teori dan penelitian terdahulu di atas kemudian digambarkan dalam kerangka hipotesis disusun sebagai berikut:

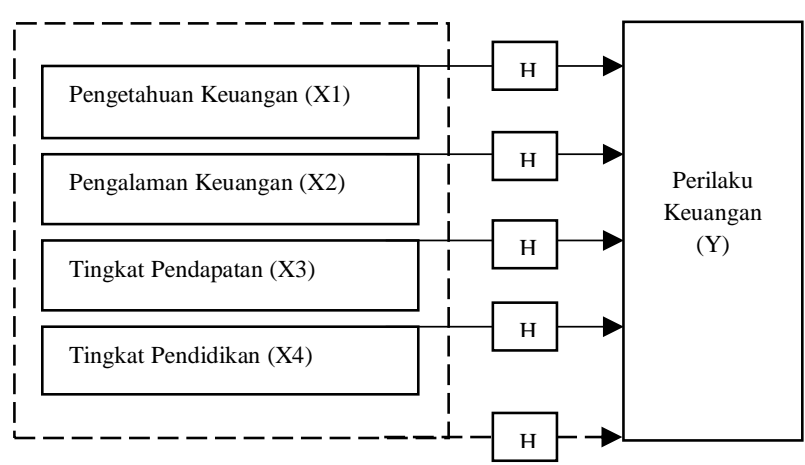

Gambar 2.2 Kerangka Penelitian Peneliti (2020)

Pengembangan Hipotesis

1. Pengaruh Pengetahuan Keuangan Terhadap Perilaku Keuangan.

Pengetahuan keuangan yaitu pemahaman atau kesanggupan seseorang tentang berbagai hal mengenai dunia keuangan. Orang dengan pengetahuan keuangan tinggi cenderung puas dengan keadaan keuangan dan terus meningkatkan kualitas hidup karena mengerti sepenuhnya atas keaadaan keuangannya saat ini dan cara memperbaikinya. Jadi apabila individu 
atau keluarga memiliki kemampuan untuk mengelola keuangan dengan baik serta menggunakan uangnya dengan bijak dan mengalokasikannya untuk memenuhi kebutuhan yang dibutuhkan maka tujuan yang diinginkan akan tercapai. Menurut penelitian Yusnia dan Jubaedah (2017), hasil perhitungan analisis statistik, pengetahuan keuangan berpengaruh positif signifikan terhadap perilaku keuangan pelaku UMKM kecamatan Cinere. Penelitian Iklima Humaira (2017), pengetahuan keuangan berpengaruh positif dan signifikan terhadap perilaku Manajemen Keuangan pada pelaku UMKM Sentra Kerajinan Batik Kabupaten Bantul.

$$
\begin{array}{rlr}
\mathrm{H} 1= & \text { Pengetahuan } & \text { Keuangan } \\
& \text { berpengaruh positif } \\
& \text { Perhadap }
\end{array}
$$

2. Pengaruh Pengalaman Keuangan Terhadap Perilaku Keuangan.

Pengalaman keuangan adalah kejadian tentang hal yang pernah dialami (dijalani, dirasakan, ditanggung dan sebagainya) baik yang sudah lama atau baru saja terjadi. Dari pengalaman keuangan dapat digunakan untuk modal dalam mengelola keuangan. Pengalaman masa kecil yang positif tentang mengelola keuangan, lingkungan sosial, dan sikap terhadap penghematan memainkan peran manajemen keuangan dalam perilaku keluarga di masa yang akan datang. Hasil penelitian Wida Purwidianti dan Rina
Mudjiyanti (2016), menunjukkan bahwa pengalaman keuangan berpengaruh positif signifikan terhadap perilaku keuangan keluarga di Kecamatan Purwokerto Timur. Penelitian Wida dan Rina (2016), pengalaman keuangan terhadap perilaku keuangan menunjukkan hasil bahwa pengalaman keuangan mempunyai pengaruh yang positif dan signifikan terhadap perilaku keuangan.
$\mathrm{H} 2=$ Pengalaman Keuangan berpengaruh positif terhadap Perilaku Keuangan.

3. Pengaruh Tingkat Pendapatan Terhadap Perilaku Keuangan.

Tingkat pendapatan merupakan total pendapatan kotor seorang individu yang berasal dari upah, gaji, usaha serta berbagai investasi. Besar kemungkinan bahwa individu dengan pendapatan yang lebih akan menunjukkan perilaku keuangan lebih bertanggung jawab, terkait dana yang tersedia memberikan kesempatan untuk bertindak lebih bertanggung jawab. Menurut penelitian Wasti Reviandani (2019), hasil perhitungan analisis statistik, tingkat pendapatan mempunyai pengaruh positif terhadap perilaku keuangan. Hal ini dapat disimpulkan bahwa tingkat pendapatan berpengaruh positif signifikan terhadap perilaku keuangan keluarga di desa Yosowilangun kecamatan Manyar Gresik. Penelitian Rizky Lianto dan Sri Megawati (2017), pendapatan berpengaruh positif 
terhadap perilaku keuangan di kalangan ibu rumah tangga palembang.

$\mathrm{H}_{3}=$ Tingkat Pendapatan berpengaruh positif terhadap Perilaku Keuangan.

4. Pengaruh Tingkat Pendidikan Terhadap Perilaku Keuangan.

Tingkat pendidikan adalah suatu proses peserta didik dalam meningkatkan pendidikan sesuai dengan jenjang yang akan di tempuhnya dalam melanjutkan pendidikan yang ditempuh. Tingkat pendidikan ditempuh secara manajerial atau terorganisir. Menurut penelitian Nurul Mahmudah (2018), tingkat pendidikan berpengaruh terhadap perilaku keuangan PNS wanita di Surabaya. Penelitian Ari Susanti, dkk (2017), tingkat pendidikan berpengaruh positif dan signifikan terhadap perilaku keuangan UMKM.

$\mathrm{H}_{4}=$ Tingkat Pendidikan berpengaruh positif terhadap Perilaku Keuangan.

5. Pengaruh Pengetahuan Keuangan, Pengalaman Keuangan, Tingkat Pendapatan dan Tingkat Pendidikan secara bersamaan Terhadap Perilaku Keuangan.

Pengaruh pengetahuan keuangan, pengalaman keuangan, tingkat pendapatan dan tingkat pendidikan terhadap perilaku keuangan. Dimana pengetahuan keuangan sangat penting dalam mengatur keuangan karena akan mendorong seseorang untuk berprilaku baik dalam mengelola keuangannya, pengalaman keuangan juga akan berperan penting dalam mengatur keuangan dimana dari pengalaman keuangan dapat digunakan untuk modal dalam mengelola keuangan untuk lebih baik, tingkat pendapatan juga berperan penting dalam perilaku keuangan seseorang, serta tingkat pendidikan juga sangat berperan penting karena dengan pendidikan yang memadai seseorang akan lebih mudah untuk mengerti dan memahami perilaku keuangan yang baik. $\mathrm{H} 5$ = Pengetahuan Keuangan, Pengalaman Keuangan, Tingkat Pendapatan dan Tingkat Pendidikan secara bersamaan berpengaruh terhadap Perilaku Keuangan.

\section{METODOLOGI PENELITIAN}

Jenis dan Sifat Penelitian

Metode penelitian adalah sekumpulan peraturan, kegiatan, dan prosedur yang digunakan oleh pelaku suatu disiplin ilmu. Metodologi juga merupakan analisis teoritis mengenai suatu cara atau metode. Penelitian merupakan suatu penyelidikan yang sistematis untuk meningkatkan sejumlah pengetahuan, juga merupakan suatu usaha yang sistematis dan terorganisasi untuk menyelidiki masalah tertentu yang memerlukan jawaban.

Pada penelitian ini, penulis mengguanakan metode penelitian kuantitatif. Metode kuantitatif adalah metode penelitian yang berlandaskan 
pada filsafat positivisme, digunakan untuk meneliti pada populasi dan sempel tertentu, teknik pengambilan sampel pada umumnya digunakan secara random, pengumpulan data menggunakan istrumen penelitian, analisis data bersifat statistik dengan tujuan untuk menguji hipotesis yang telah ditetapkan (Sugiyono, 2013).

Adapun pengertian metode kuantitatif, adalah metode penelitian yang didasarkan pada realitas, gejala maupun fenomena yang dapat diamati dan dirukur serta memiliki hubungan sebab akibat yang digunakan untuk meneliti populasi atau sampel tertentu dengan menggunakan instrumen penelitian. Serta analisis data statistik yang bertujuan untuk menguji hipotesis.Selain itu, metode ini menggunakan data penelitian berupa angka-angka dan analisis menggunakan statistik.

Jenis penelitian ini adalah penelitian lapangan (field research), yaitu peneliti langsung dilakukan dilapangan atau pada responden. Berdasarkan sifat penelitianya, penelitian ini merupakan penelitian asosiatif kausal. Penelitian asosiatif kausal adalah penelitian yang bertujuan untuk menganalisis hubungan antara satu variabel dengan variabel yang lain. Arah dan tujuan penelitian ini untuk mengetahui pengaruh pengetahuan keuangan, pengalaman keuangan, tingkat pendapatan, dan tingkat pendidikan terhadap perilaku keuangan.

\section{Populasi dan Sampel}

Populasi adalah wilayah generalisasi yang terdiri atas obyek/subyek yang mempunyai kualitas dan karakteristik tertentu yang ditetapkan oleh peneliti untuk dipelajari dan kemudian ditarik kesimpulan (Sugiyono, 2013). Populasi dalam penelitian ini Kepala Keluarga di Kabupaten Subang, dengan memenuhi kriteria yang ditentukan yaitu Pegawai
Negeri, Pegawai Swasta, Karyawan, dan Buruh. Peneliti memilih kriteria tersebut karena mengikuti saran dari penelitian sebelumnya.

Menurut Sugiyono (2013) teknik sampling adalah teknik pengambilan sampel. Untuk menentukan sampel yang akan digunakan pada penelitian terdapat berbagai teknik sampling yang dapat digunakan.

Teknik pengambilan sampel yang digunakan dalam penelitin ini adalah Non Probability Sampling yakni pengambilan sampel yang tidak memberi kesempatan yang sama bagi setiap unsur atau anggota populasi untuk dipilih menjadi sampel (Sugiyono, 2016). Dimana peneliti menetapkan Sampling Insidental sebagai teknik pengambilan sampelnya. Sampling Insidental adalah teknik penentuan sampel berdasarkan kebetulan, yaitu siapa saja yang secara kebetulan bertemu dengan peneliti yang dapat digunakan sebagai sampel, bila dipandang orang yang kebetulan ditemui cocok sebagai sumber data.

Dalam penelitian ini jumlah populasinya tidak diketahui, sehingga penentuan ukuran sampel dari populasi menggunakan teori yang dikembangkan Bentler dan Chou (1987), merekomendasikan jumlah sampel minimal adalah 5 kali dari jumlah pernyataan yang terdapat dalam kuesioner penelitian. Sehingga minimal ukuran sampel penelitian ini sebagai berikut $16 \times 5=80$, maka sampel yang harus dipenuhi untuk estimasi sebanyak 80 (Bentler dan chou, 1987).

\section{Teknik Pengumpulan Data}

Pada penelitian jenis data yang akan digunakan adalah data primer dan data sekunder. Data primer diperoleh dengan 
penyebarkan kuesioner. Sementara data sekunder diperoleh dari buku, jurnal dan referensi kepustakaan lainnya.

Definisi Operasional Variabel

Operasional adalah suatu definisi yang didasarkan pada karakteristik yang dapat diobservasi dari apa yang sedang didefinisikan. Adapun dalam penelitian ini variabel independen adalah Pengetahuan Keuangan, Pengalaman Keuangan, Tingkat Pendapatan, dan Tingkat Pendidikan (X), sedangkan variabel dependen adalah Perilaku Keuangan (Y).

Tabel 3.1

Operasional Variabel Pengetahuan Keuangan, Peengalaman Keuangan, Tingkat Pendapatan dan Tingkat Pendidikan

\begin{tabular}{|c|c|c|c|}
\hline Variabel & Definisi & Indikator & $\begin{array}{c}\text { Skal } \\
\text { a }\end{array}$ \\
\hline $\begin{array}{l}\text { Pengetah } \\
\text { uan } \\
\text { Keuanga } \\
n(X 1)\end{array}$ & $\begin{array}{l}\text { Pengetah } \\
\text { uan } \\
\text { mengacu } \\
\text { pada apa } \\
\text { yang } \\
\text { diketahui } \\
\text { individu } \\
\text { tentang } \\
\text { masalah } \\
\text { keuangan } \\
\text { pribadi, } \\
\text { yang } \\
\text { diukur } \\
\text { dengan } \\
\text { tingkat } \\
\text { pengetahu } \\
\text { an mereka } \\
\text { tentang } \\
\text { berbagai } \\
\text { konsep } \\
\text { keuangan } \\
\text { pribadi } \\
\text { (Marsh, } \\
\text { 2006). }\end{array}$ & 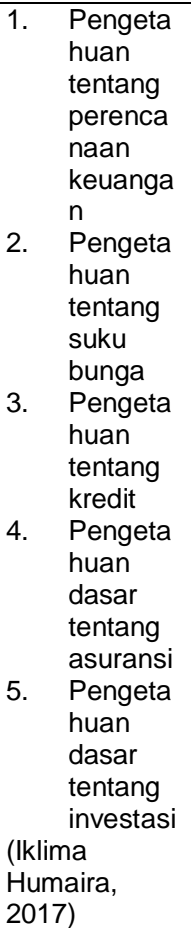 & Likert \\
\hline $\begin{array}{l}\text { Pengalam } \\
\text { an } \\
\text { Keuanga } \\
\mathrm{n}(\mathrm{X} 2)\end{array}$ & $\begin{array}{l}\text { Pengalam } \\
\text { an } \\
\text { keuangan } \\
\text { adalah } \\
\text { kejadian } \\
\text { tentang } \\
\text { hal yang } \\
\text { pernah }\end{array}$ & $\begin{array}{l}\text { 1. Pengala } \\
\text { man } \\
\text { menyusu } \\
\mathrm{n} \\
\text { perencan } \\
\text { aan } \\
\text { pemasuk } \\
\text { an dan }\end{array}$ & Likert \\
\hline
\end{tabular}

\begin{tabular}{|c|c|c|c|}
\hline Variabel & Definisi & Indikator & $\begin{array}{c}\text { Skal } \\
\text { a }\end{array}$ \\
\hline & $\begin{array}{l}\text { dialami } \\
\text { (dijalani, } \\
\text { dirasakan, } \\
\text { ditanggun } \\
\text { g, dan } \\
\text { sebagainy } \\
\text { a), baik } \\
\text { yang } \\
\text { sudah } \\
\text { lama atau } \\
\text { baru saja } \\
\text { terjadi. } \\
\text { Dari } \\
\text { pengalam } \\
\text { an } \\
\text { keuangan } \\
\text { dapat } \\
\text { digunakan } \\
\text { untuk } \\
\text { modal } \\
\text { dalam } \\
\text { mengelola } \\
\text { keuangan } \\
\text { (Ritma dan } \\
\text { Untung,20 } \\
\text { 15). }\end{array}$ & $\begin{array}{l}\text { pengelua } \\
\text { ran } \\
\text { Pengala } \\
\text { man } \\
\text { membuat } \\
\text { laporan } \\
\text { pengelua } \\
\text { ran dan } \\
\text { pemasuk } \\
\text { an } \\
\text { Pengala } \\
\text { man } \\
\text { dalam } \\
\text { mengana } \\
\text { lisis } \\
\text { pencatat } \\
\text { an } \\
\text { laporan } \\
\text { keuanga } \\
\text { n } \\
\text { (Yulianti \& } \\
\text { Silvy, 2013) }\end{array}$ & \\
\hline $\begin{array}{l}\text { Tingkat } \\
\text { Pendapat } \\
\text { an (X3) }\end{array}$ & $\begin{array}{l}\text { Tingkat } \\
\text { pendapata } \\
\mathrm{n} \text { adalah } \\
\text { total } \\
\text { pendapata } \\
\mathrm{n} \text { kotor } \\
\text { tahunan } \\
\text { seorang } \\
\text { individu } \\
\text { yang } \\
\text { berasal } \\
\text { dari upah, } \\
\text { perusahaa } \\
\mathrm{n} \text { bisnis } \\
\text { dan } \\
\text { berbagai } \\
\text { investasi } \\
\text { (Andrew } \\
\text { dan } \\
\text { Linawati, } \\
\text { 2014). }\end{array}$ & 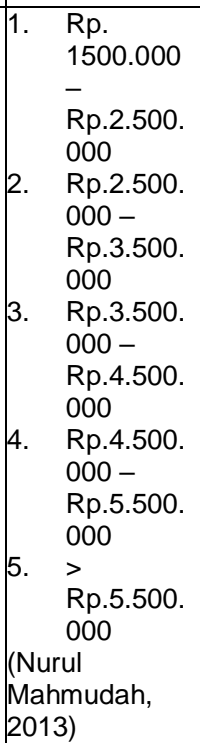 & $\begin{array}{c}\text { Ordin } \\
\text { al }\end{array}$ \\
\hline $\begin{array}{l}\text { Tingkat } \\
\text { Pendidika } \\
\text { n (X4) }\end{array}$ & $\begin{array}{l}\text { Pendidika } \\
\mathrm{n} \\
\text { merupaka } \\
\mathrm{n} \text { kegiatan } \\
\text { yang } \\
\text { dijalankan } \\
\text { dengan } \\
\text { usaha dan } \\
\text { terencana } \\
\text { dalam } \\
\text { penguasa } \\
\text { an ilmu } \\
\text { pengetahu } \\
\text { an guna } \\
\text { untuk } \\
\text { mengubah } \\
\text { tingkah } \\
\text { laku yang } \\
\text { diinginkan } \\
\text { dan pembentu } \\
\text { kem pola }\end{array}$ & $\begin{array}{l}\text { 1. SMP } \\
\text { 2. SMA } \\
\text { 3. Diploma } \\
\text { 4. Sarjana } \\
\text { 5. Pascasa } \\
\text { rjana } \\
\text { (Nurul } \\
\text { Mahmudah, } \\
\text { 2013) }\end{array}$ & $\begin{array}{c}\text { Ordin } \\
\text { al }\end{array}$ \\
\hline
\end{tabular}




\begin{tabular}{|c|c|c|c|}
\hline Variabel & Definisi & Indikator & Skal \\
\hline & $\begin{array}{l}\text { pikir yang } \\
\text { lebih baik } \\
\text { (Annora } \\
\text { Paramitha } \\
\text { Rustiaria, } \\
\text { 2017). }\end{array}$ & & \\
\hline $\begin{array}{l}\text { Perilaku } \\
\text { Keuanga } \\
\mathrm{n}(\mathrm{Y})\end{array}$ & $\begin{array}{l}\text { Perilaku } \\
\text { keuangan } \\
\text { adalah } \\
\text { kemampu } \\
\text { an } \\
\text { seseorang } \\
\text { dalam } \\
\text { mengatur } \\
\text { keuangan } \\
\text { yang lebih } \\
\text { bertanggu } \\
\text { ng jawab } \\
\text { (Kholilah } \\
\text { dan } \\
\text { Iramani, } \\
\text { 2013). }\end{array}$ & $\begin{array}{l}\text { 1. Perencan } \\
\text { aan } \\
\text { keuanga } \\
\mathrm{n} \text { untuk } \\
\text { masa } \\
\text { depan } \\
\text { 2. Pembaya } \\
\text { ran } \\
\text { tagihan } \\
\text { tepat } \\
\text { waktu } \\
\text { 3. Penyisiha } \\
\text { n uang } \\
\text { untuk } \\
\text { tabungan } \\
\text { (Wida \& Rina, } \\
\text { 2016) }\end{array}$ & Likert \\
\hline
\end{tabular}

referensi (2020)

Teknik Analisis Data

Analisis data diartikan sebagai upaya data yang sudah tersedia kemudian diolah dengan statistik dan dapat digunakan untuk menjawab rumusan masalah dalam penelitian. Dengan demikian teknik analisis data dapat diartikan sebagai cara melakasanakan analisis terhadap data, dengan tujuan mengelola data tersebut untuk menjawab rumusan masalah.

\section{Pengujian Instrument Penelitian}

a. Uji Validitas

Uji validitas adalah ukuran yang sebenarnya, untuk mengukur apa yang akan diukur. Uji validitas yaitu ketepatan dan kecermatan tes dalam menjalankan fungsi pengukurannya.

Validitas juga merupakan suatu ukuran yang menunjukan tingkatan-tingkatan kevalidan dan kesahihan suatu instrumen. Suatu instrumen yang valid atau sahih mempunyai validitas tinggi, sebaliknya instrumen yang kurang valid atau sahih mempunyai validitas yang rendah.

Uji validitas digunakan untuk mengetahui kelayakan butir kelayakan butir-butir dalam suatu daftar pertanyaan dalam mendefinisikan suatu variabel.

Signifikan atau tidaknya penelitian ini dapat dilihat pada kolom atau baris total score, jika pada kolom atau baris tersebut masing-masing total butir pertanyaan mnghasilkan tanda bintang, berarti data tersebut signifikan.

b. Uji Reliabilitas

Uji Reliabilitas menunjukan pada suatu pengertian bahwa sesuatu instrumen cukup dapat dipercaya untuk digunakan sebagai alat pengumpul data karena instrumen tersebut sudah baik.

Reliabilitas instrumen menggambarkan pemantapan dan keajegan alat ukur yang digunakan. Oleh karena itu, pengujian reliabilitas angket dimaksudkan untuk mengetahui sejauh mana konsistensi hasil pengukuran yang dilakukan.

Metode Analisis Data

Analisis dalam penelitian ini menggunakan data primer yang diperoleh dengan menyebarkan kuisoner kepada responden yang akan diteliti. Pada penelitian ini untuk mengolah daata menggunakan program SPSS (Statistical Package for Sosial Science). SPSS digunakan untuk menguji hipotesis dikemukakan.

1) Uji Asumsi Klasik

a. Normalitas

Untuk menguji apakah dalam model regresi variabel 
pengganggu atau residual memiliki distribusi normal (Ghozali, 2013:160). Ada dua cara untuk mendeteksi apakah residual berdistribusi normal atau tidak yaitu dengan analisis grafik dan uji statistik.

Uji statistik yang digunakan untuk menguji normalitas residual dalam penelitian ini adalah uji statistik nonparametrik KolmogrovSmirnov (K-S). Uji K-S dilakukan dengan membuat hipotesis:

1. Jika hasil Kolmogrov-

Smirnov menunjukkan nilai signifikan > 0,05 maka hipotesis diterima karena data residual terdistribusi dengan normal.

2. Jika hasil KolmogrovSmirnov menunjukkan nilai signifikan < 0,05 maka hipotesis ditolak karena data residual terdistribusi tidak normal.

b. Heteroskedastisitas Uji heteroskedastisitas bertujuan untuk menguji apakah dalam model regresi terjadi ketidaksamaan variance dari residual satu pengamatan ke pengamatan lainnya. Jika variance dari residual satu pengamatan ke pengamatan yang lain tetap, maka disebut homokedastisitas.

Sedangkan, jika berbeda disebut heteroskedastisitas. Model regresi yang baik adalah yang homokedastisitas dan tidak terjadi heteroskedastisitas
(Ghozali, 2013). Uji heteroskedastisitas yang dilakukan dalam program SPSS ini digunakan uji Scatter Plot. Jika titik-titik pada hasil gambar Scatter Plot menyebar secara acak diatas dan dibawah angka 0 maka dapat disimpulkan tidak terjadi heteroskedastisitas.

c. Multikoloneritas

Multikoliniaritas pertama kali dikemukakan oleh Ragner Frish. Frish mengatakan multikoliniaritas adalah adananya lebih dari satu hubungan linier yang sempurna (koefisien korelasi antar variabel $=1$ ), maka koefesian regresi dari variabel bebas tidak dapat ditentukan dan standar erornya tidak terhingga. (Suharyadi dan Purwanto, 2009 : 231-232). Jika multikolinieritas kurang sempurna, maka koefisien regresi meskipun behingga akan mempunyai standar deviasi yang besar berarti pula koefisiennya tidak dapat ditaksir dengan mudah. Analisis deteksi adanya multikolinieritas adalah sebagai berikut:

a) Besaran Varian Inflation Faktor (VIF) dan Tolerance

Pedoman suatu model regresi yang bebas multiko adalah mempunyai nilai VIF disekitar angka 1 dan tidak melebihi angka 10 dan mempunyai angka toleransi mendekati 1. 
b) Besaran korelasi antar variabel independen

Pedoman suatu model regresi yang bebas dari multiko adalah koefisien korelasi antar variabel independen haruslah lemah.

2) Regresi Linear Berganda

Model regresi adalah model yang digunakan untuk mengetahui pengaruh hubungan antara variabel independen dengan varibel dependen apakah masingmasing variabel independen berhubungan positif atau negative untuk memprediksi nilai dari variabel dependen apabila nilai variabel independen mengalami kenaikan atau penurunan (Ferdinand, 2006). Sedangkan menurut Sugiono (2005) analisis regresi berganda digunakan untuk meramalkan bagaimana keadaan variabel dependen sebagai faktor prediktor dimanipulasi. Model ini diguanakan untuk mengetahui besarnya $Y$ dan $X$.

Formula untuk analisis ini adalah:

$$
\begin{gathered}
Y=\alpha+\beta 1 X 1+\beta 2 X 2+\beta 3 X 3+ \\
\beta 4 X 4+\mu
\end{gathered}
$$

Keterangan:

$\mathrm{Y}=$ Perilaku Keuangan

$\alpha=$ Konstanta

$\mathrm{X} 1$ = Pengetahuan Keuangan

$\mathrm{X} 2$ = Pengalaman Keuangan

X3 $=$ Tingkat Pendapatan

X4 = Tingkat Pendidikan

$\beta=$ Koefesien Regresi

$\mathrm{e}=$ Error

3) Uji Hipotesis
Hipotesis adalah dugaan sementara dari suatu masalah dan merupakan penuntun untuk melakukan penelitian.

Ketetapan fungsi regresi sampel dalam menaksir nilai aktual dapat diukur melalui Goodness Of fit-nya. Secara statistik hal ini dapat diukur melalui nilai statistik $t$, nilai statistik $f$ dan nilai koofesien determninan. Apabila uji statistik berada dalam daerah kritis (daerah dimana $\mathrm{HO}$ ditolak), pengujian tersebut bermakna signifikan. Sedangkan disebut tidak signifikan apabila nilai uji statistiknya berada dalam daerah dimana $\mathrm{HO}$ diterima.

a. Uji T (Parsial)

Uji $t$ adalah pengujian koefisien regresi parsial individual yang digunakan untuk mengetahui apakah variabel indipenden $(X)$ secara individual mempengaruhi variabel dependen $(\mathrm{Y})$.

b. Uji F (Simultan)

Uji $F$ adalah pengujian signifikansi persamaan yang digunakan untuk mengetahui seberapa besar pengaruh variabel bebas secara bersamasama terhadap variabel tidak bebas. Penggunaan tingkat signifikasinya 0.05 (5\%). Jika nilai probabilitas $<0,05$ maka terdapat pengaruh signifikan. Namun, jika nilai signifikan > 0,05 maka tidak terdapat pengaruh yang signifikan secara bersamaa-sama antara variabel bebas terhadap variabel terikat.

c. Uji koefisien determinasi

Koefesien determinasi (goodness of fit), yang 
dinotasikan dengan merupakan suatu ukuran yang penting dalam regresi. Determinan mencerminkan kemampuan variabel dependen. Tujuan analisis ini adalah untuk menghitung besarnya pengaruh variabel independen terhadap variabel dependen. Nilai $R^{2}$ menunjukkan seberapa besar proporsi dari total variasi variabel tidak bebas yang dapat dijelaskan oleh variabel penjelasnya. Semakin tinggi nilai $\mathrm{R}^{2}$ maka besar proposi dan total variasi variabel dependen yang dapat dijelaskan oleh variabel independen.

\section{HASIL DAN PEMBAHASAN}

Hasil Penelitian

Deskriptif Data Penelitian

Data penelitian ini diperoleh dengan cara membagikan kuesioner dalam bentuk online dibagikan melalui online dengan cara dibagikan melalui media sosial. Kuesioner dibagikan kepada kepala keluarga di kabupaten subang. Penyebaran kuesioner dilakukan kurang lebih 40 hari, mulai dari 27 Maret 2020 sampai dengan 06 Mei 2020. Kuesioner yang disebarkan adalah sebanyak 160 dengan rincian sebagai berikut:

Tabel 4.1

Rincian

Penyebaran Kuesioner

\begin{tabular}{|c|c|c|c|}
\hline $\mathrm{N}$ & Keteranga & Jumla & Persentas \\
$\mathrm{o}$ & $\mathrm{n}$ & $\mathrm{h}$ & $\mathrm{e}$ \\
\hline
\end{tabular}

\begin{tabular}{|c|l|c|c|}
\hline 1 & $\begin{array}{l}\text { Total } \\
\text { kuesioner } \\
\text { yang } \\
\text { disebar }\end{array}$ & 160 & $100 \%$ \\
\hline 2 & $\begin{array}{l}\text { Total } \\
\text { kuesioner } \\
\text { yang } \\
\text { terkumpul }\end{array}$ & 120 & $75 \%$ \\
\hline
\end{tabular}

Sumber : Data diolah, 2020

\section{Karakteristik Responden}

Responden yang berpartisipasi dalam penelitian ini berjumlah 120 responden yang sesuai dengan kriteria yang ditetapkan oleh peneliti. Dari penyebaran angket atau kuesioner ini peneliti menyebarkan 120 kuesioner kepada responden yang sesuai dengan persyaratan.

Gambaran umum responden diperoleh dari identitas diri responden yang tercantum pada masing-masing jawaban terhadap kuesioner. Untuk mendapatkan gambaran mengenai karakteristik responden, maka data yang diperoleh dibagi dalam beberapa kriteria yaitu berdasarkan: usia, pendidikan, pendapatan dan pekerjaan sebagaimana data dan tabel dibawah ini :

1. Usia

Berdasarkan kuesioner yang disebar pada 120 responden, diperoleh data mengenai usia responden. Berikut data mengenai usia responden sebagaimana tabel dibawah ini :

Tabel 4.2

Klasifikasi Responden Berdasarkan Usia

\begin{tabular}{|c|c|c|}
\hline \multirow{2}{*}{ Usia } & \multicolumn{2}{|c|}{$\begin{array}{c}\text { Tanggapan } \\
\text { Responden }\end{array}$} \\
\cline { 2 - 3 } & $\begin{array}{c}\text { Ora } \\
\text { ng }\end{array}$ & $\%$ \\
\hline $\begin{array}{c}20- \\
30\end{array}$ & 69 & 57,5 \\
\hline
\end{tabular}




\begin{tabular}{|c|c|c|}
\hline $\begin{array}{c}\text { Tahu } \\
\mathrm{n}\end{array}$ & & \\
\hline $\begin{array}{c}31- \\
40\end{array}$ & 39 & 32,5 \\
$\begin{array}{c}\text { Tahu } \\
\mathrm{n}\end{array}$ & & \\
\hline $\begin{array}{c}41- \\
50\end{array}$ & 11 & 9,2 \\
$\begin{array}{c}\text { Tahu } \\
\mathrm{n}\end{array}$ & & \\
\hline $\begin{array}{c}>50 \\
\text { Tahu } \\
\mathrm{n}\end{array}$ & 1 &, 8 \\
\hline $\begin{array}{c}\text { TOT } \\
\mathrm{AL}\end{array}$ & 120 & $\begin{array}{c}100 \\
0\end{array}$ \\
\hline
\end{tabular}

Sumber : Data diolah, 2020

Dari tabel 4.2 di atas, dapat dilihat bahwa usia responden 20 - 30 tahun sebesar $57,5 \%$ atau sebanyak 69 orang, usia 31 - 40 tahun sebesar $32,5 \%$ atau sebanyak 39 orang, usia 40 - 50 tahun sebesar $9,2 \%$ atau sebanyak 11 orang, dan usia $>50$ tahun sebesar $0,8 \%$ atau sebanyak 1 orang.

\section{Pendidikan}

Berdasarkan kuesioner yang disebar pada 120 responden, diperoleh data mengenai pendidikan responden. Berikut data mengenai pendidikan responden sebagaimana tabel dibawah ini :

Tabel 4.3

Klasifikasi Responden Berdasarkan Pendidikan

\begin{tabular}{|c|c|c|}
\hline \multirow{2}{*}{ Pendidikan } & \multicolumn{2}{|c|}{$\begin{array}{c}\text { Tanggapan } \\
\text { Responden }\end{array}$} \\
\cline { 2 - 3 } & Orang & $\%$ \\
\hline SMP & 0 &, 0 \\
\hline SMA & 68 & 56,7 \\
\hline Diploma & 1 &, 8 \\
\hline Sarjana & 45 & 37,5 \\
\hline Pascasarjana & 6 & 5,0 \\
\hline TOTAL Sumber : Data diolah, \\
\hline \multicolumn{3}{|c}{ SOT } \\
\hline \multirow{2}{*}{ SO20 }
\end{tabular}

Dari tabel 4.3 di atas, dapat dilihat bahwa pendidikan responden SMP sebesar $0 \%$ atau sebanyak 0 orang, SMA sebesar $56,7 \%$ atau sebanyak 68 orang, Diploma sebesar $0,8 \%$ atau sebanyak 1 orang, Sarjana sebesar $37,5 \%$ atau sebanyak 45 orang, dan Pascasarjana sebesar $5,0 \%$ atau sebanyak 6 orang.

\section{Pendapatan}

Berdasarkan kuesioner yang disebar pada 120 responden, diperoleh data mengenai pendapatan responden. Berikut data mengenai pendapatan responden sebagaimana tabel dibawah ini :

Tabel 4.4

Klasifikasi Responden

Berdasarkan Pendapatan

\begin{tabular}{|c|c|c|}
\hline \multirow[t]{2}{*}{ Pendapatan } & \multicolumn{2}{|c|}{$\begin{array}{l}\text { Tanggapan } \\
\text { Responden }\end{array}$} \\
\hline & Orang & $\%$ \\
\hline $\begin{array}{l}\text { Rp. } 1.500 .000- \\
\text { Rp. } 2.500 .00\end{array}$ & 31 & 25,8 \\
\hline $\begin{array}{l}\text { Rp. } 2.500 .000- \\
\text { Rp. } 3.500 .00\end{array}$ & 35 & 29,2 \\
\hline $\begin{array}{l}\text { Rp. } 3.500 .000- \\
\text { Rp. } 4.500 .000\end{array}$ & 25 & 20,8 \\
\hline $\begin{array}{l}\text { Rp. } 4.500 .000- \\
\text { Rp. } 5.500 .00\end{array}$ & 18 & 15,0 \\
\hline$>$ Rp. 5.500 .000 & 11 & 9,2 \\
\hline TOTAL & 120 & 100,0 \\
\hline
\end{tabular}

Dari tabel 4.4 di atas, dapat dilihat bahwa pendapatan responden $\mathrm{Rp}$. 1.500 .000 - Rp. 2.500 .000 sebesar $25,8 \%$ atau sebanyak 31 orang, Rp. 2.500 .000 Rp. $\quad 3.500 .000$ sebesar $29,2 \%$ atau sebanyak 35 orang, Rp. 3.500 .000 - Rp. 4.500 .000 sebesar $20,8 \%$ atau sebanyak 25 orang, Rp. 4.500 .000 - Rp. 5.500 .000 sebesar $15,0 \%$ atau sebanyak 18 orang, dan > Rp. 5.500 .000 sebesar $59,2 \%$ atau sebanyak 11 orang.

4. Pekerjaan 
Berdasarkan kuesioner yang disebar pada 120 responden, diperoleh data mengenai pekerjaan responden. Berikut data mengenai pekerjaan responden sebagaimana tabel dibawah ini :

Tabel 4.5

Klasifikasi Responden

Berdasarkan Pekerjaan

\begin{tabular}{|c|c|c|}
\hline \multirow{2}{*}{ Pekerjaan } & \multicolumn{2}{|c|}{$\begin{array}{c}\text { Tanggapan } \\
\text { Responden }\end{array}$} \\
\cline { 2 - 3 } & Orang & $\%$ \\
\hline Karyawan & 50 & 41,7 \\
\hline Pegawai Negeri & 27 & 22,5 \\
\hline Pegawai swasta & 43 & 35,8 \\
\hline TOTAL & 120 & 100,0 \\
\hline \multicolumn{2}{|c|}{ Sumber : Data diolah, } \\
2020
\end{tabular}

Dari tabel 4.5 di atas, dapat dilihat bahwa pekerjaan responden Karyawan sebesar $41,7 \%$ atau sebanyak 50 orang, Pegawai Negeri sebesar 22,5\% atau sebanyak 27 orang, dan Pegawai Swasta sebesar $35,8 \%$ atau sebanyak 43 orang.

\section{Analisis Statistik Deskriptif}

Tabel 4.6

Statistik Deskriptif

Descriptive Statistics

\begin{tabular}{|c|c|c|c|c|c|}
\hline & $\mathrm{N}$ & $\begin{array}{c}\text { Minim } \\
\text { um }\end{array}$ & $\begin{array}{l}\text { Maxi } \\
\text { mum }\end{array}$ & Mean & $\begin{array}{c}\text { Std. } \\
\text { Deviatio } \\
\mathrm{n}\end{array}$ \\
\hline $\begin{array}{l}\text { Pengetahuan } \\
\text { Keuangan }\end{array}$ & 120 & 23 & 45 & 36,54 & 4,892 \\
\hline $\begin{array}{l}\text { Pengalaman } \\
\text { Keuangan }\end{array}$ & 120 & 6 & 15 & 12,12 & 2,423 \\
\hline $\begin{array}{l}\text { Tingkat } \\
\text { Pendapatan }\end{array}$ & 120 & 1 & 5 & 2,53 & 1,277 \\
\hline $\begin{array}{l}\text { Tingkat } \\
\text { Pendidikan }\end{array}$ & 120 & 2 & 5 & 2,91 & 1,069 \\
\hline $\begin{array}{l}\text { Perilaku } \\
\text { Keuangan }\end{array}$ & 120 & 12 & 20 & 17,89 & 2,114 \\
\hline $\begin{array}{l}\text { Valid N } \\
\text { (listwise) }\end{array}$ & & & & & \\
\hline
\end{tabular}

Sumber : Data diolah, 2020
Berdasarkan tabel 4.6 di atas menunjukan variabel pengetahuan keuangan memiliki nilai mean 36,54 dengan standar deviasi sebesar 4,892; variabel pengalaman keuangan memiliki nilai mean 12,12 dengan standar deviasi sebesar 2,423; variabel tingkat pendapatan memiliki mean 2,53 dengan standar deviasi sebesar 1,277; variabel tingkat pendidikan memiliki nilai mean 2,91 dengan standar deviasi sebesar 1,069; variabel perilaku keuangan memiliki mean 17,89 dengan standar deviasi sebesar 2,114

Analisis Data dan Pengujian Hipotesis Uji Validitas dan Reliabilitas

1. Uji Validitas

Tabel 4.7

Hasil Uji Validitas Variabel Pengetahuan keuangan (X1)

\begin{tabular}{|c|c|c|c|}
\hline Variabel & $\begin{array}{c}r \\
\text { Hitung }\end{array}$ & $\begin{array}{c}r \\
\text { Tabel } \\
(120) \\
5 \%\end{array}$ & Keterangan \\
\hline X1.1 & 0,525 & 0,179 & Valid \\
\hline X1.2 & 0,787 & 0,179 & Valid \\
\hline X1.3 & 0,689 & 0,179 & Valid \\
\hline X1.4 & 0,633 & 0,179 & Valid \\
\hline X1.5 & 0,711 & 0,179 & Valid \\
\hline X1.6 & 0,666 & 0,179 & Valid \\
\hline X1.7 & 0,570 & 0,179 & Valid \\
\hline X1.8 & 0,600 & 0,179 & Valid \\
\hline X1.9 & 0,534 & 0,179 & Valid \\
\hline
\end{tabular}

Sumber : Data diolah, 2020

Tabel 4.8

Hasil Uji Validitas Variabel

Pengalaman keuangan (X2)

\begin{tabular}{|c|c|c|c|}
\hline Variabel & $\begin{array}{c}r \\
\text { Hitung }\end{array}$ & $\begin{array}{c}r \\
\text { Tabel } \\
(120) \\
5 \%\end{array}$ & Keterangan \\
\hline X2.1 & 0,718 & 0,179 & Valid \\
\hline X2.2 & 0,833 & 0,179 & Valid \\
\hline X2.3 & 0,779 & 0,179 & Valid \\
\hline
\end{tabular}

Sumber : Data diolah, 2020

Tabel 4.9

Hasil Uji Validitas Variabel Perilaku keuangan ( $\mathrm{Y}$ )

\begin{tabular}{|c|c|c|c|}
\hline Variabel & $\begin{array}{c}r \\
\text { Hitung }\end{array}$ & $\begin{array}{c}r \\
\text { Tabel }\end{array}$ & Keterangan \\
\hline
\end{tabular}




\begin{tabular}{|l|l|c|l|}
\hline & & $\begin{array}{c}(120) \\
5 \%\end{array}$ & \\
\hline Y1 & 0,587 & 0,179 & Valid \\
\hline Y2 & 0,626 & 0,179 & Valid \\
\hline Y3 & 0,667 & 0,179 & Valid \\
\hline Y4 & 0,504 & 0,179 & Valid \\
\hline
\end{tabular}

Sumber : Data diolah, 2020

Berdasarkan hasil perhitungan uji validitas bahwa semua $r$ hitung lebih besar dari $r$ tabel pada nilai signifikansi $5 \%$ sehingga dapat disimpulkan bahwa indikator dalam kuesioner penelitian ini valid sehingga dapat digunakan sebagai instrumen penelitian.

2. Uji Reliabilitas

Pengujian reliabilitas adalah proses pengujian butir-butir pernyataan yang ada dalam sebuah kuesioner, apakah isi dari butir pernyataan tersebut reliabel sehingga dapat mengukur faktornya. Untuk melihat andal tidaknya suatu alat ukur digunakan pendekatan secara statistika, yaitu melalui koefesien reliabilitas. Suatu variabel dikatakan reliabel jika nilai cronbach's alpha (a) > 0,60 (Nunnali) dalam Imam Gozali (2013:47).

Berdasarkan penelitian yang dilakukan dengan bantuan komputer pada program SPSS for windows versi 20.0 untuk uji reliabilitas dari masing-masing variabel yang terdiri dari Pengetahuan Keuangan (XI), Pengalaman Keuangan (X2), Tingkat Pendapatan (X3), Tingkat Pendidikan (X4), dan Perilaku Keuangan (Y) dimana hasilnya bisa dilihat pada tabel berikut ini:

Tabel 4.10

Hasil uji Reliabilitas Statistic

\begin{tabular}{|l|c|c|c|}
\hline Variabel & $\begin{array}{c}\text { Cronbach } \\
\text { 's Alpha }\end{array}$ & $\begin{array}{c}\text { Imam } \\
\text { Ghoz } \\
\text { ali } \\
(2013)\end{array}$ & $\begin{array}{c}\text { Keterang } \\
\text { an }\end{array}$ \\
\hline $\begin{array}{l}\text { Pengetahu } \\
\text { an } \\
\text { Keuangan }\end{array}$ & 0,884 & 0,60 & Reliabel \\
\hline
\end{tabular}

\begin{tabular}{|l|c|c|c|}
\hline $\begin{array}{l}\text { Pengalama } \\
\mathrm{n} \\
\text { Keuangan }\end{array}$ & 0,884 & 0,60 & Reliabel \\
\hline $\begin{array}{l}\text { Perilaku } \\
\text { Keuangan }\end{array}$ & 0,783 & 0,60 & Reliabel \\
\hline
\end{tabular}

Sumber : Data diolah, 2020

Berdasarkan tabel 4.10 di atas, hasil uji reliabilitas variabel Pengetahuan Keuangan memiliki nilai cronbach's alpha 0,884, variabel Pengalaman Keuangan memiliki nilai cronbach's alpha 0,884 , dan variabel Perilaku Keuangan memiliki nilai cronbach's alpha 0,783. Semua variabel dinyatakan reliabel karena nlai cronbach's alpha (a) $>0,60$. Hal ini sesuai dengan teori dari (Imam Ghozali 2013:47).

\subsubsection{Uji Asumsi Klasik}

1. Uji Normalitas

Untuk menguji apakah dalam model regresi variabel pengganggu atau residual memiliki distribusi normal (Ghozali, 2013:160). Ada dua cara untuk mendeteksi apakah residual berdistribusi normal atau tidak yaitu dengan analisis grafik dan uji statistik. Uji statistik yang digunakan untuk menguji normalitas residual dalam penelitian ini adalah uji statistik nonparametrik Kolmogrov-Smirnov (K-S). Uji K-S dilakukan dengan membuat hipotesis:

a. Jika hasil Kolmogrov-Smirnov menunjukkan nilai signifikan > 0,05 maka hipotesis diterima karena data residual terdistribusi dengan normal.

b. Jika hasil Kolmogrov-Smirnov menunjukkan nilai signifikan < 0,05 maka hipotesis ditolak karena data residual terdistribusi tidak normal.

Tabel 4.11

Hasil Uji Normalitas

\begin{tabular}{|c|c|c|}
\hline Model & $\begin{array}{c}\text { Asymp. Sig } \\
\text { (2-tailed) }\end{array}$ & Keterangan \\
\hline
\end{tabular}




\begin{tabular}{|c|c|c|}
$\begin{array}{c}\text { X1, X2, } \\
\text { X3, X4 } \\
\text { dan Y }\end{array}$ & $\begin{array}{c}0,413> \\
0,05\end{array}$ & Normal \\
\hline \multicolumn{3}{|c|}{ Sumber : Data diolah, 2020} \\
\hline
\end{tabular}

Berdasarkan hasil uji normalitas dalam penelitian ini diketahui nilai signifikansi 0,413>0,05 maka dapat disimpulkan bahwa nilai residual berdistribusi normal.

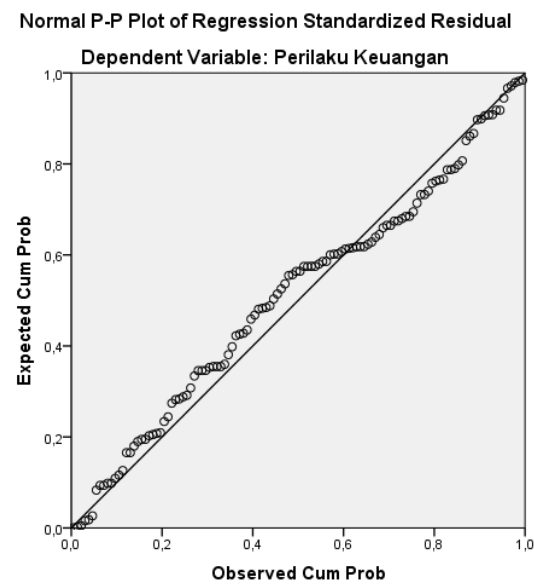

Gambar 4.5

Grafik Normal P-P Plot

Sumber : Data diolah, 2020

Berdasarkan hasil grafik pada gambar di atas, terlihat titik-titik menyebar di sekitar garis dan mengikuti arah garis diagonal, dengan demikian dapat disimpulkan bahwa residu dalam model regresi berdistribusi secara normal (Umiyati dan Nurmalasari,2016).

2. Uji Heteroskedastisitas

Uji heteroskedastisitas bertujuan untuk menguji apakah dalam model regresi terjadi ketidaksamaan variance dari residual satu pengamatan ke pengamatan lainnya. Jika variance dari residual satu pengamatan ke pengamatan yang lain tetap, maka disebut homokedastisitas. Sedangkan, jika berbeda disebut heteroskedastisitas. Model regresi yang baik adalah yang homokedastisitas dan tidak terjadi heteroskedastisitas (Ghozali, 2013). Uji heteroskedastisitas yang dilakukan dalam program SPSS ini digunakan uji Scatter Plot. Jika titik-titik pada hasil gambar Scatter Plot menyebar secara acak di atas dan dibawah angka 0 maka dapat disimpulkan tidak terjadi heteroskedastisitas. Berikut adalah hasil dari uji heteroskedastisitas.

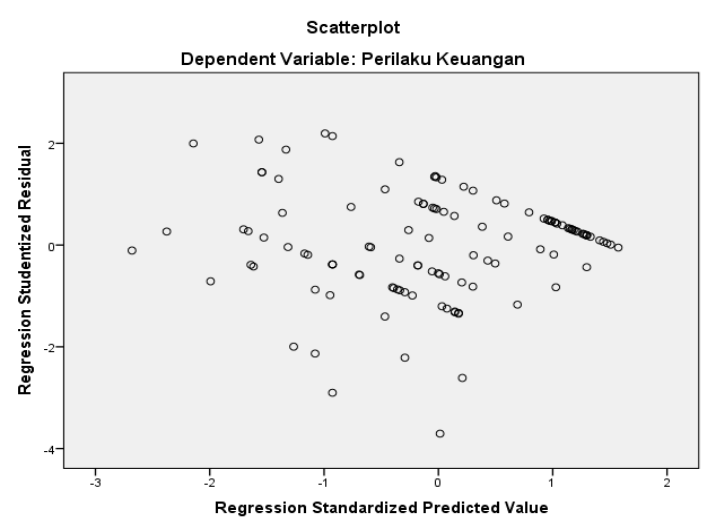

Gambar 4.6

Hasil Uji Heteroskedastisitas

Sumber : Data diolah, 2020

Berdasarkan gambar 4.6 di atas terlihat bahwa titik-titik menyebar secara acak serta tersebar baik di atas maupun dibawah angka 0 pada sumbu Y. Hal ini dapat disimpulkan bahwa tidak terjadi heteroskedastisitas, sehingga model regresi layak dipakai untuk memprediksi variabel dependen berdasarkan variabel independen.

3. Uji Multikoloneritas

Pengujian Multikoloneritas dilakukan dengan pedoman suatu model regresi yang bebas multiko adalah mempunyai nilai Varian Inflation Faktor (VIF) disekitar angka 1 dan tidak melebihi angka 10 dan mempunyai angka tolerance mendekati 1. Nilai kedua variabel 
bebas pada model regresi adalah sebagaimana tabel di bawah ini :

Tabel 4.12

Uji Multikolonieritas

\begin{tabular}{|c|c|c|}
\hline Variabel & Tolerance & VIF \\
\hline $\mathrm{X} 1$ & 0,778 & 1,286 \\
\hline $\mathrm{X} 2$ & 0,788 & 1,268 \\
\hline $\mathrm{X} 3$ & 0,807 & 1,240 \\
\hline $\mathrm{X} 4$ & 0,807 & 1,239 \\
\hline
\end{tabular}

Sumber : Data diolah, 2020

Berdasarkan Tabel 4.12 di atas keempat variabel independent (bebas) memiliki nilai varian Inflation Faktor (VIF) disekitar angka 1 dan tidak melebihi angka 10 dan mempunyai angka tolerance mendekati 1. Dimana variabel pengetahuan keuangan mempunyai nila VIF $=1,286$ dan nilai tolerance $=$ 0,778. Variabel pengalaman keuangan mempunyai nila VIF = 1,268 dan nilai tolerance $=0,788$. Variabel tingkat pendapatan mempunyai nila VIF $=1,240$ dan nilai tolerance $=0,807$. Variabel tingkat pendidikan mempunyai nila VIF = 1,239 dan nilai tolerance $=0,807$. Jadi dapat disimpulkan bahwa tidak terjadi Multikoloneritas antar variabel bebas model regresi.

\subsubsection{Uji Hipotesis}

Tabel 4.13

Hasil Uji Regresi

\begin{tabular}{|c|c|c|c|}
\hline Variabel & Coefficient & $\mathrm{T}$ & Sig \\
\hline Constant & 10,624 & 8,891 & 0,000 \\
\hline X1 & 0,045 & 1,313 & 0,192 \\
\hline X2 & 0,511 & 7,405 & 0,000 \\
\hline X3 & $-0,202$ & - & 0,121 \\
\hline
\end{tabular}

\begin{tabular}{|c|c|c|c|}
\hline X4 & $-0,023$ & - & 0,881 \\
\hline F hitung & \multicolumn{3}{|c|}{21,895} \\
\hline Sig. F & \multicolumn{2}{|c|}{0,000} \\
\hline $\mathrm{R}^{2}$ & \multicolumn{2}{|c|}{0,432} \\
\hline
\end{tabular}

Sumber : Data diolah, 2020

1. Uji Regresi Linear Berganda

Hasil analisis regresi berganda menghasilkan koefisien untuk variabel bebas yaitu $X_{1}=0.045 ; X_{2}=0,511 ; X_{3}$ $=-0.202 ;$ dan $X_{4}=-0.023$ dengan konstanta 10,624. Dengan demikian, dapat dihasilkan persamaan regresi berganda sebagai berikut:

$Y=10,624+0,045+0,511-0,202$ $-0,023 Y+e$

Persamaan regresi berganda di atass memiliki makna sebagai berikut :

a. Konstanta sebesar 10,624 artinya jika variabel Pengetahuan Keuangan, Pengalaman Keuangan, Tingkat Pendapatan dan Tingkat Pendidikan bernilai 0 , maka perilaku keuangan akan bernilai 10,624.

b. Koefesien regresi pengetahuan keuangan $\left(X_{1}\right)$ sebesar 0,045, mengartikan bahwa jika pengetahuan keuangan mengalami peningkatan satu satuan, maka perilaku keuangan juga akan mengalami peningkatan sebesar 0,045 satuan.

c. Koefesien regresi pengalaman keuangan (X2) sebesar 0,511, mengartikan bahwa jika pengalaman keuangan mengalami peningkatan satu satuan, maka perilaku keuangan juga akan mengalami peningkatan sebesar 0,511 satuan.

d. Koefesien regresi tingkat pendapatan (X3) sebesar -0,202, mengartikan bahwa jika tingkat pendapatan mengalami penurunan satu satuan, maka 
perilaku keuangan akan mengalami peningkatan sebesar sebesar 0,202.

e. Koefesien regresi tingkat pendidikan $\left(\mathrm{X}_{4}\right)$ sebesar -0,023, mengartikan bahwa jika tingkat pendidikan mengalami penurunan satu satuan, maka perilaku keuangan akan mengalami peningkatan sebesar 0,023 .

\section{Uji T (Parsial)}

Pengujian hipotesis membandingkan nilai t hitung dengan $t$ tabel atau sering disebut juga dengan uji t, dimana dasar pengambilan keputusan dalam uji t adalah:

a. Jika nilai t hitung lebih besar dari t tabel maka ada pengaruh Pengetahuan Keuangan $\left(X_{1}\right)$, Pengalaman Keuangan $\left(X_{2}\right)$, Tingkat Pendapatan $\left(\mathrm{X}_{3}\right)$, dan Tingkat Pendidikan $\left(\mathrm{X}_{4}\right)$ terhadap Perilaku Keuangan (Y).

b. Sebaliknya, jika nilai t hitung lebih kecil dari t tabel maka tidak ada pengaruh

Pengetahuan Keuangan $\left(X_{1}\right)$, Pengalaman Keuangan $\left(X_{2}\right), \quad$ Tingkat Pendapatan $\left(X_{3}\right)$, dan Tingkat Pendidikan $\left(\mathrm{X}_{4}\right)$ terhadap Perilaku Keuangan $(Y)$.

Berikut adalah penjelasan hasil uji $t$ dari setiap variabel :

a. Hipotesis pertama $(\mathrm{H} 1)$

Variabel pengetahuan keuangan $\left(X_{1}\right)$ memiliki nilai t hitung sebesar $(1,313)$ lebih kecil dari $t$ tabel $(<1,980)$ dan nilai signifikan $(0,192)$ lebih besar dari $(>0,05)$, ini menunjukkan bahwa pengetahuan keuangan tidak berpengaruh terhadap perilaku keuangan. Dengan demikian hipotesis pertama $\left(\mathrm{H}_{1}\right)$ ditolak karena variabel pengetahuan keuangan tidak berpengaruh terhadap perilaku keuangan.

b. Variabel pengalaman keuangan $\left(X_{2}\right)$ memiliki nilai t hitung sebesar $(7,405)$ lebih besar dari $t$ tabel $(>1,980)$ dan nilai signifikan $(0,000)$ lebih kecil dari $(<0,05)$, ini menunjukkan bahwa pengalaman keuangan berpengaruh positif terhadap perilaku keuangan. Dengan demikian hipotesis kedua $\left(\mathrm{H}_{2}\right)$ diterima karena variabel pengalaman keuangan berpengaruh positif terhadap perilaku keuangan.

c. Variabel tingkat pendapatan $\left(\mathrm{X}_{3}\right)$ memiliki nilai $t$ hitung sebesar ($1,563)$ lebih kecil dari $t$ tabel $(<1,980)$ dan nilai signifikan $(0,121)$ lebih besar dari $(>0,05)$, ini menunjukkan bahwa tingkat pendaptan tidak berpengaruh terhadap perilaku keuangan. Dengan demikian hipotesis ketiga $\left(\mathrm{H}_{3}\right)$ ditolak karena variabel tingkat pendapatan tidak berpengaruh terhadap perilaku keuangan.

d. Variabel tingkat pendidikan $\left(\mathrm{X}_{4}\right)$ memiliki nilai $t$ hitung sebesar ($0,150)$ lebih kecil dari $t$ tabel $(<1,980)$ dan nilai signifikan $(0,881)$ lebih besar dari $(>0,05)$, ini menunjukkan bahwa tingkat pendidikan tidak berpengaruh terhadap perilaku keuangan. Dengan demikian hipotesis keempat $\left(\mathrm{H}_{4}\right)$ ditolak karena variabel tingkat pendidikan tidak berpengaruh terhadap perilaku keuangan.

3. Uji F (Simultan)

Uji $F$ adalah pengujian signifikansi persamaan yang digunakan untuk mengetahui seberapa besar pengaruh variabel bebas secara bersama-sama terhadap variabel 
tidak bebas. Penggunaan tingkat signifikasinya 0.05 (5\%). Jika nilai signifikan < 0,05 maka terdapat pengaruh signifikan. Namun, jika nilai signifikan > 0,05 maka tidak terdapat pengaruh yang signifikan secara bersamaa-sama antara variabel bebas terhadap variabel terikat.

Berdasarkan tabel di atas diketahui nilai $F$ hitung sebesar 21,898 dan signifikansi sebesar 0,000 . Karena $F$ hitung $(21,898)$ dan nilai signifikansi $(0,000)$ lebih kecil dari 0,05 maka dapat disimpulkan bahwa $\mathrm{H} 5$ diterima, artinya tingkat Pengetahuan Keuangan, Pengalaman Keuangan, Tingkat Pendapatan dan Tingkat Pendidikan secara bersama-sama (simultan) berpengaruh signifikan terhadap Perilaku Keuangan.

4. Uji Koefisien Determinasi

Koefesien determinasi (goodness of fit), yang dinotasikan dengan merupakan suatu ukuran yang penting dalam regresi. Determinan mencerminkan kemampuan variabel dependen. Tujuan analisis ini adalah untuk menghitung besarnya pengaruh variabel independen terhadap variabel dependen. Nilai $R^{2}$ menunjukkan seberapa besar proporsi dari total variasi variabel tidak bebas yang dapat dijelaskan oleh variabel penjelasnya. Semakin tinggi nilai $R^{2}$ maka besar proposi dan total variasi variabel dependen yang dapat dijelaskan oleh variabel independen.

Hasil perhitungan regresi dalam penelitian ini dapat diketahui bahwa koefisien determinasi yang diperoleh sebesar 0,432. Hal ini berarti 43,2\% Perilaku Keuangan dipengaruhi oleh Pengetahuan Keuangan, Pengalaman Keuangan, Tingkat Pendapatan dan Tingkat Pendidikan sedangkan sisanya $56,8 \%$ Perilaku
Keuangan dipengaruhi oleh variabel lainnya yang tidak diteliti dalam penelitian ini.

\subsection{Pembahasan}

4.3.1 Pengaruh Pengetahuan

Keuangan Terhadap Perilaku

Keuangan

Berdasarkan hasil uji statistik yang

telah dilakukan menunjukkan bahwa tidak adanya pengaruh dari variabel pengetahuan keuangan terhadap perilaku keuangan. Hal tersebut dapat dilihat dari hasil statistik uji secara parsial yang ditunjukkan dengan $\mathrm{X}_{1}$ dimana nilai t-hitug lebih kecil dari t-tabel $(1,313<$ $1.980)$ dan nilai signifikan $(0,192>0,05)$, maka hipotesis pertama $(\mathrm{H} 1)$ dalam penelitian ini ditolak yang menyatakan bahwa pengetahuan keuangan tidak berpengaruh terhadap perilaku keuangan.

Jika dihubungkan dengan teori tentang pengetahuan keuangan, penelitian ini tidak sejalan dengan teori yang menyatakan bahwa pengetahuan keuangan akan sangat penting fungsinya bagi yang sudah berkeluarga. Pemahaman tentang pengetahuan keuangan mendorong seseorang untuk berperilaku baik dalam pengelolaan keuangannya untuk jangka panjang. Tingginya pengetahuan keuangan seseorang akan cenderung memiliki perilaku keuangan yang baik (Andrew, 2014). Pengetahuan keuangan adalah kemampuan seseorang untuk mendapatkan, memahami, dan mengevaluasi informasi yang relevan 
untuk mengambil keputusan dengan memahami konsekuensi yang di timbulkannya (Mason dan Wilson, 2000). Pengetahuan keuangan menjadi hal tak terpisahkan dalam kehidupan karena merupakan salah satu alat yang berguna untuk mengambil keputusan keuangan (Orton, 2007).

Sedangkan penelitian ini menunjukkan bahwa tidak adanya pengaruh pengetahuan keuangan terhadap perilaku keuangan, hal ini menunjukkan bahwa pengetahuan keuangan yang dimiliki kepala keluarga di Subang tinggi, tetapi belum tentu kepala keluarga dengan pengetauan yang tinggi memilki perilaku keuangan yang buruk. Ini mencerminkan bahwa kepala keluarga telah menyiapkan sebagian dananya untuk membayar kewajiban dengan tepat waktu. Sehingga ketika sudah jatuh tempo untuk membayar tagihan maka responden siap membayarkan dana yang sudah disisihkan, dan kepala keluarga memiliki kesadaran yang tinggi untuk menyisihkan dananya sebagai antisipasi kebutuhan tak terduga dan untuk masa depan.

Penelitian ini sejalan dengan penelitan terdahulu yang dilakukan oleh Lianto dan Elizabeth (2017) yang menemukan bukti bahwa pengetahuan keuangan tidak mempunyai pengaruh terhadap perilaku keuangan, hal ini disebabkan oleh tidak semua atau hanya sebagian kecil responden memiliki pengetahuan keuangan yang baik.

Implikasi masalah pengetahuan keuangan yaitu berguna untuk mengambil keputusan keuangan. Dalam penelitian ini menunjukkan bahwa pengetahuan keuangan yang dimiliki kepala keluarga tinggi yang artinya sebagian besar kepala keluarga mengetahui / memahami pengetahuan keuangan. Pengetahuan yang tinggi bermanfaat agar terhindar dari kesulitan keuangan contohnya adalah melakukan perencanaan keuangan. Seseorang yang memiliki perencanaan keuangan adalah suatu hal yang penting. Dana yang disishkan dapat digunakan sebagai dana cadangan sewaktu-waktu dapat digunakan dalam kondisi darurat atau untuk berinvestasi.

\subsubsection{Pengaruh Pengalaman Keuangan Terhadap Perilaku Keuangan \\ Berdasarkan hasil uji statistik yang} telah dilakukan menunjukkan bahwa adanya pengaruh dari variabel pengalaman keuangan terhadap perilaku keuangan. Hal tersebut dapat dilihat dari hasil statistik uji secara parsial yang ditunjukkan dengan $X_{2}$ dimana nilai $t-$ hitung lebih besar dari t tabel $(7,405>$ $1.980)$ dan nilai signifikan $(0,000<0,05)$, maka hipotesis kedua $(\mathrm{H} 2)$ dalam penelitian ini diterima yang menyatakan bahwa pengalaman keuangan berpengaruh positif terhadap perilaku keuangan.

Penelitian ini menjelaskan bahwa adanya pengaruh positif antara pengalaman keuangan terhadap perilaku 
keuangan, yang menunjukkan bahwa pengalaman keuangan kepala keluarga di Kabupaten Subang meningkat akan membuat perilaku keuangan juga meningkat. Menurut Hilgert dan Jeanne (2013), keputusan keuangan yang baik dan benar dibutuhkan untuk meningkatkan pendapatan, mengelola pengeluaran, agar manajemen keuangan keluarga menjadi baik. Pengalaman yang positif tentang mengelola keuangan, akan menumbuhkan perilaku keuangan keluarga yang baik di masa yang akan datang.

Penelitian ini sejalan dengan penelitan terdahulu yang dilakukan oleh Purwidianti dan Mudjiyanti (2016) yang menemukan bukti bahwa pengalaman keuangan mempunyai pengaruh positif terhadap perilaku keuangan.

Implikasi masalah pengalaman keuangan yaitu sebagai modal dalam mengatur keuangan, khususnya dalam merencanakan,mencatat dan menganalisis keuangan. perencanaan keuangan yang baik sebagian besar diperoleh dari pengalaman masa kecil yang positif, seperti melakukan penghematan dan menabung. Banyaknya pengalaman yang diperoleh tersebut akan memperbaiki kondisi keuangan sampai di masa yang akan datang.

\subsubsection{Pengaruh Tingkat Pendapatan Terhadap Perilaku Keuangan}

Berdasarkan hasil uji statistik yang telah dilakukan menunjukkan bahwa tidak adanya pengaruh dari variabel tingkat pendapatan. Hal tersebut dapat dilihat dari hasil statistik uji secara parsial yang ditunjukkan dengan $X_{3}$ dimana nilai t-hitug lebih kecil dari t-tabel $(-1,563<1.980)$ dan nilai signifikan $(0,121>0,05)$, maka hipotesis ketiga $(\mathrm{H} 3)$ dalam penelitian ini ditolak yang menyatakan bahwa tingkat pendapatan tidak berpengaruh terhadap perilaku keuangan.

Menurut Al kholilah dan Irmani (2013) pada saat tingkat pendapatannya meningkat maka perilaku keuangannya menurun, hal ini dimungkinkan responden yang memiliki pendapatan rendah lebih mudah dalam mengalokasikan keuangan yang dimilikinya.

Sedangkan penelitian ini menunjukkan bahwa tidak adanya pengaruh tingkat pendapatan terhadap perilaku keuangan, hal ini dikarenakan responden dalam penelitian ini adalah kepala keluarga dengan tingkat pendapatan yang berbeda. Sehingga setiap kepala keluarga dalam mengalokasikan keuangan yang dimilikinya akan berbeda dan pendapatan tidak lagi menjadi faktor utama dalam mengelola keuangan keluarga, karena tidak semua kepala keluarga yang memiliki pendapatan tinggi akan mengelola keuangannya dengan baik dan sebaliknya, tidak semua kepala keluarga dengan pendapatan rendah tidak mengelola keuangannya dengan baik.

Penelitian ini sejalan dengan penelitan yang dilakukan oleh Purwidianti dan Mudjiyanti (2016) yang menemukan bukti bahwa tingkat pendapatan tidak mempunyai pengaruh terhadap perilaku keuangan.

$$
\text { Implikasi masalah tingkat }
$$
pendapatan yaitu berguna untuk 
perencanaan keuangan. Tingkat pendapatan dalam penelitian ini tinggi, hal ini mennjukkan pendapatan yang tinggi akan lebih memiliki ruang untuk menyisihkan pendapatan yang diperoleh dan dapat mengalokasikan pendapatan yang diperoleh untuk keperluan investasi, asuransi, dan bahkan merencanakan dana pensiun.

\subsubsection{Pengaruh Tingkat Pendidikan \\ Terhadap Perilaku Keuangan}

Berdasarkan hasil uji statistik yang telah dilakukan menunjukkan bahwa tidak adanya pengaruh dari variabel tingkat pendidikan. Hal tersebut dapat dilihat dari hasil statistik uji secara parsial yang ditunjukkan dengan $\mathrm{X}_{4}$ dimana nilai t-hitug lebih kecil dari t-tabel $(-0,150<1.980)$ dan nilai signifikan $(0,881>0,05)$, maka hipotesis keempat $(\mathrm{H} 4)$ dalam penelitian ini ditolak yang menyatakan bahwa tingkat pendidikan tidak berpengaruh terhadap perilaku keuangan.

Tingkat pendidikan adalah suatu proses peserta didik dalam meningkatkan pendidikan sesuai dengan jenjang yang akan di tempuhnya dalam melanjutkan pendidikan yang ditempuh. Tingkat pendidikan ditempuh secara manajerial atau terorganisir (Adhanari, 2005).

Penelitian ini menunjukkan bahwa responden yang jenjang pendidikannya tinggi belum tentu memiliki perilaku keuangan keluarga yang baik. Begitu juga sebaliknya, tidak semua responden dengan pendidikan rendah mempunyai perilaku keuangan keluarga yang buruk. Hal ini menunjukkan bahwa semakin tinggi tingkat pendidikan, maka orang tersebut akan memiliki kesempatan yang lebih besar untuk memperoleh informasi baik mengenai pengetahuan keuangan, life style maupun perkembangan teknologi. Informasi tersebut akan menjadi bekal seseorang untuk berprilaku keuangan yang baik. Namun tidak semua orang yang memiliki informasi tersebut akan menerapkannya dalam kehidupan seharihari termasuk dalam mengelola keuangan keluarga. Hal ini dimungkinkan karena pengetahuan tentang perilaku keuangan keluarga tidak hanya didapat dari pendidikan formal, tetapi bisa didapatkan dari pendidikan non formal dan budaya di keluarga serta lingkungan sekitar. Sehingga, bisa dikatakan bahwa pengaruh tingkat pendidikan terhadap perilaku keuangan keluarga tidak signifikan.

Hasil penelitian ini sejalan dengan hasil penelitian sebelumnya yang dilakukan oleh Paramitha (2017) yang menyatakan bahwa tingkat pendidikan tidak berpengaruh terhadap perilaku pengelolaan keuangan keluarga.

Implikasi tingkat pendidikan yaitu berguna untuk mengembangkan kemampuan, sikap, dan bentuk tingkah laku, baik untuk kehidupan masa kini dan sekaligus persiapan bagi kehidupan masa yang akan datang dimana melalui organisasi tertentu ataupun tidak terorganisir.

\subsubsection{Pengaruh Pengetahuan Keuangan, Pengalaman Keuangan, Tingkat Pendapatan dan Tingkat Pendidikan Terhadap Perilaku Keuangan \\ Berdasarkan hasil statistik Uji F} secara bersama-sama (simultan) menunjukkan bahwa adanya pengaruh dari variabel pengetahuan keuangan, pengalaman keuangan, tingkat pendapatan, dan tingkat pendidikan secara simultan berpengaruh terhadap perilaku keuangan. Hal tersebut dapat dilihat dari hasil statistik uji F (simultan) yang menunjukan bahwa nilai $F$ hitung $(21,898>2.45)$ dan nilai signifikansi $(0,000<0,05)$, ini berarti pengetahuan keuangan, pengalaman keuangan, tingkat pendapatan dan tingkat pendidikan secara bersama-sama 
(simultan) berpengaruh signifikan terhadap perilaku keuangan. Namun berdasarkan nilai Adjusted $R$ Square $\left(R^{2}\right)$ sebesar 0,432. Hal ini berarti 43,2\% Perilaku Keuangan dipengaruhi oleh Pengetahuan Keuangan, Pengalaman Keuangan, Tingkat Pendapatan dan Tingkat Pendidikan sedangkan sisanya $56,8 \%$ Perilaku Keuangan dipengaruhi oleh variabel lainnya yang tidak diteliti dalam penelitian ini. Dari hasil tersebut menunjukkan bahwa hipotesis kelima (H5) dalam penelitian ini diterima yang menyatakan pengetahuan keuangan, pengalaman keuangan, tingkat pendapatan dan tingkat pendidikan berpengaruh terhadap perilaku keuangan.

\section{KESIMPULAN}

Berdasarkan hasil analisis dan pembahasan mengenai pengaruh pengetahuan keuangan, pengalaman keuangan, tingkat pendapatan, dan tingkat pendidikan terhadap perilaku keuangan, maka kesimpulan yang dapat diambil dalam penelitian ini adalah:

1. Berdasarkan hasil uji hipotesis pertama, maka dapat ditarik kesimpulan dilihat dari hasil statistik yaitu pengetahuan keuangan tidak berpengaruh terhadap perilaku keuangan. Hal ini menunjukkan bahwa paham atau tidaknya seseorang mengenai pengetahuan keuangan tidak mempengaruhi perilaku keuangannya.

2. Berdasarkan hasil uji hipotesis kedua, maka dapat ditarik kesimpulan dilihat dari hasil statistik yaitu pengalaman keuangan berpengaruh positif signifikan terhadap perilaku keuangan. Hal ini menunjukkan bahwa pengalaman yang positif tentang mengelola keuangan akan menumbuhkan perilaku keuangan keluarga menjadi baik.

3. Berdasarkan hasil uji hipotesis ketiga, maka dapat ditarik kesimpulan dilihat dari hasil statistik yaitu tingkat pendapatan tidak berpengaruh terhadap perilaku keuangan. Hal ini menunjukkan bahwa besar kecilnya pendapatan yang dimiliki kepala keluarga tidak akan berpengaruh terhadap perilaku keuangan.

4. Berdasarkan hasil uji hipotesis keempat, maka dapat ditarik kesimpulan dilihat dari hasil statistik yaitu tingkat pendidikan tidak berpengaruh terhadap perilaku keuangan. Hal ini menunjukkan bahwa responden yang jenjang pendidikannya tinggi belum tentu memiliki perilaku keuangan keluarga yang baik. Begitu juga sebaliknya, tidak semua responden dengan pendidikan rendah mempunyai perilaku keuangan keluarga yang buruk.

5. Berdasarkan hasil uji hipotesis kelima, secara simultan bahwa pengetahuan keuangan, pengalaman keuangan, tingkat pendapatan, dan tingkat pendidikan secara simultan berpengaruh signifikan terhadap perilaku keuangan. Sehingga $\mathrm{H} 5$ diterima.

\section{KETERBATASAN}

Berdasarkan pada pengalaman dalam menyusun penelitian ini ada beberapa keterbatasan yang dialami peneliti dan dapat menjadi beberapa faktor yang agar dapat untuk lebih diperhatikan bagi peneliti-peneliti yang akan datang dalam menyempurnakan penelitiannya karna penelitian ini sendiri tentu memiliki kekurangan yang perlu terus diperbaiki dalam penelitian-penelitian kedepannya. Beberapa keterbatasan dalam penelitian tersebut, diantaranya : 
1. Jumlah responden yang hanya 120 orang, tentunya masih kurang untuk menggambarkan keadaan yang sesungguhnya.

2. Dalam proses pengambilan data/kuesioner peneliti tidak bisa menemui langsung responden sehingga menyebabkan tidak maksimal karena dimasa pandemi Covid-19 dan diberlakukannya Pembatasan Sosial Berskala Besar (PSBB) untuk wilayah Jawa Barat Khususnya di Kabupaten Subang, sehingga peneliti memutuskan untuk melakukan pengambilan data/kuesioner secara daring/online. Informasi yang diberikan responden melalui kuesioner terkadang tidak menunjukkan pendapat responden yang sebenarnya, hal ini terjadi karena kadang perbedaan pemikiran, anggapan dan pemahaman yang berbeda tiap responden, juga faktor lain seperti faktor kejujuran dalam pengisian pendapat responden dalam kuesionernya.

\section{SARAN}

Berdasarkan hasil penelitian, pembahasan, dan kesimpulan yang diperoleh, maka saran yang dapat diberikan oleh peneliti adalah sebagai berikut:

1. Bagi kepala keluarga

Sebaiknya dalam menerapkan akuntansi rumah tangga ini dilakukan secara rutin dan berkelanjutan yang diharapkan dapat mengontrol seluruh pengeluaran setiap bulannya agar ada sisa pendapatan yang dapat digunakan untuk kebutuhan yang tidak terduga.

2. Bagi peneliti selanjutnya

a. Peneliti selanjutnya disarankan untuk menambah variabel lain selain variabel yang diteliti agar dapat melengkapi penelitian ini dalam mempengaruhi perilaku keuangan keluarga. Misalnya locus of control dan orientasi masa depan. Penulis menyarankan variabel locus of control karena locus of control merupakan faktor yang berperan penting yang menentukan baik tidaknya perilaku keuangan. Penulis menyarankan orientasi masa depan karena orientasi masa depan merupakan suatu usaha masa kini yang memiliki pengaruh terhadap kegiatan yang ingin dicapai di masa depan melalui proses yang berkelanjutan.

b. Diharapkan pada penelitian yang akan datang jumlah sampel yang digunakan bisa lebih banyak.

c. Dalam menyebar kuesioner peneliti selanjutnya disarankan untuk melakukan pendampingan pada responden dalam pengisian kuesioner untuk mengantisipasi responden dalam mengisi pernyataan yang terdapat pada kuesioner.

\section{DAFTAR PUSTAKA}

Al-Kholilah, N. \& Iramani, (2013). Studi Financial Management Behavior Pada Masyarakat Surabaya, Journal of Business and Banking, 3(1): 69-80.

Andrew dan Linawati, 2014. Hubungan Faktor Demografi dan Pengetahuan Dengan Perilaku 
Keuangan Kaaryawan Swasta di Surabaya. Vol. 2, No. 2.

Asti, Maria.Adhanari, 2005. Pengaruh Tingkat Pendidikan Terhadap Produktivitas Kerja Karyawan Bagian Produksi Pada Maharani Handicraft di Kabupaten Bantul. Skripsi. Semarang: Program Sarjana Fakultas Immu Sosial Univesitas Negri Semarang

Augusty, Ferdinand, 2006. Metode Penelitian Manajemen: Pedoman Penelitian untuk skripsi, Tesis dan Disertai IImu Manajemen. Semarang: Universitas Diponegoro.

Darman dan sadalia, 2012. Analisis Personal Financial Literacy dan Financial Behavior Mahasiswa Sastra I Fakultas Ekonomi Universitas Sumatera Utara. Vol. 1 , No. 1.

Dian Anita Sari, 2015. Financial Literacy dan Perilaku Keuangan Mahasiswa. Jurnal Buletin Bisnis dan Manajemen. Vol. 1, No. 2 (2015).

Ghozali, Imam. 2013. Aplikasi Analisis Multivariate dengan Program IBM SPSS 21 Update PLS Regresi. Semarang: Badan Penerbit Universitas Diponegoro.

Halim, Y. K. E., \& Astuti, D. (2015). Financial Stressors, Financial Behaviour, Risk Tolerance, Financial Solvency, Financiaal Knownledge, dan Kepuasan Finansial. Finesta, 3(1), 19-23.

Ida dan Dwinta, 2010. Pengaruh Locus of Control Financial Knowledge Income Terhadap Financial Management Behavior. Jurnal Bisnis dan Akuntansi, Vol. 12, No. 3.

Lewis Mandell and Linda Schmid Klein, 2009. The Impact of Financial Literacy Education on
Subsequent Financial Behavior. Vol. 20, No. 1 (2009).

Ni Made Rai Jurniariani dan Made Gede Wirakusuma, 2015. Pengaruh Pengetahuan Akuntansi Dan Jiwa Kewirausahaan Pada Penggunaan Informasi Akuntansi Dalam Pembuatan Keputusan Investasi. Vol.21.No.2. (2015).

Nur dan Nadia, 2018. Pengaruh Demografi, Financial Knowledge, Financial Attitude, Locus Of Control Dan Financial SelfEfficacy Terhadap Financial Management Behavior Masyarakat Surabaya. Jurnal IImu Manajemen, Vol. 6, No. 3 (2018).

Ritma Pritazahara dan Untung Sriwidodo, 2015. Pengaruh Pengetahuan Keuangan Dan Pengalaman Keuangan Terhadap Perilaku Perencanaan Investasi Dengan Self Control Sebagai Variabel Moderating. Jurnal Ekonomi dan Kewirausahaan Vol. 15 No. 1. (2015).

Rizky Lianto dan Sri Megawati Elizabeth, 2017. Analisis Pengaruh Financial Attitude, Financial Knoeledge, Income Terhadap Financial Behavior Di Kalangan Ibu Rumah Tangga Palembang.

Siska Widyaningrum, 2018. Pengaruh Sikap Keuangan, Pengetahuan Keuangan dan Pengalaman Keuangan Terhadap Perilaku Pengelolaan Keuangan Keluarga di Sidoarjo.

Sugiyono, 2005. Metode Penelitian Bisnis. Bandung: Alfabeta.

Sugiyono, 2011. Metode Penelitian Kuantitatif, Kualitatif dan R\&D. Bandung: Afabeta.

Sugiyono, 2013. Metodelogi Penelitian Kuantitatif, Kualitatif Dan R\&D. Bandung: Alfabeta. 
Suharyadi dan Purwanto. 2009. Statistika Untuk Ekonomi Dan Keuangan Modern Edisi 2 Buku 2. Jakarta: Salemba Empat.

Suryanto, 2017. Pola Perilaku Keuangan Mahasiswa di Perguruan Tinggi. Jurnal IImu Politik dan Komunikasi, Vol. 7, No. 1.

Tri Rachmat Riski dan Masruri, 2019. Literasi Keuangan dan Perilaku Keuangan Pada Mahasiswa Perguruan Tinggi Swasta di kota Padang. Jurnal Manajemen dan Kewirausahaan, Vol. 10, No. 1. Undang-undang Nomor 2 Tahun 1989. Tentang Sistem Pendidikan Nasional

Perry, Vanessa G. and Marlene D. Morris (2005). The Role of Self Perception, Knowledg, and Income in Explaining Consumer Financial Behaviour. Journal of Consumer Affairs. Vol. 29, No. 2. pp. $299-313$.

Pradiningtyas dan Lukiastuti, 2019. Pengaruh Pengetahuan Keuangan dan Sikap Keuangan
Terhadap Locus Of Control dan Perilaku Pengelolaan Keuangan Mahasiswa Ekonomi. Jurnal Manajemen Ide dan Inspirasi, Vol. 6, No. 1.

Pritazahara dan Sriwidodo, 2015. Pengaruh Pengetahuan Keuangan dan Pengalaman Keuangan Terhadap Perilaku Perencanaan Investasi Dengan Self Control Sebagai Variabel Moderating, Vol. 15, No. 1.

Purwidianti, W. \& Mudjiyanti, R. (2016). Analisis Pengaruh Pengalaman Keuangan dan Tingkat Pendapatan Terhadap Perilaku Keuangan Keluarga di Kecamatan Purwokerto Timur, Jurnal Manajemen dan Bisnis, Vol. 1, No 2 : 141-148.

Wasti Reviandi, 2019. Pengaruh Pengalaman Keuangan dan Tingkat Pendapatan Terhadap Perilaku Keuangan Keluarga di Desa Yosowilangun Kecamatan Manyar Gresik. Jurnal Ekonomi dan Bisnis. 